\title{
On the Ecology and Distribution of Ecbinococcus spp. (Cestoda: Taeniidae), and Characteristics of their Development in the Intermediate Host
}

\author{
Sur l'Ecologie \\ et la distribution géographique \\ d'Echiconoccus spp. (Cestoda : Taenidae): \\ Caractéristiques du développement chez l'hôte intermédaire (1) \\ by Robert L. RAUSCH
}

Investigation of the parasite-host relationships of Echinococcus granulosus (Batsch, 1786 ) and E. multilocularis Leuckart, 1863, was begun more than one hundred years ago with the rearing of the adult E. granulosus in experimentally infected dogs by von Siebold (1853), and with the recognition by Zeller (1854) of the protoscolices of the species later designated E. multilocularis in hepatic lesions from a case of \& alveolar colloid $\gg$ of man. Following confirmation of the specific distinction of E. multilocularis and the establishment of the causality of alveolar hydatid disease of man, intensified study of the Cestodes of the genus Echinococcus Rudolphi, 1801, has placed these Cestodes among the best known of the parasitic helminths. The significance of some of their biological peculiarities has remained controversial, however, because differences between the two comparatively well known species have been frequently misinterpreted.

Three species of Echinococcus [E. granulosus, E. multilocularis, and E. oligarthrus (Diesing, 1863)] were recognized as valid by Rausch and Nelson (1963), and two (E. felidis Ortlepp, 1937, and E. patagonicus Szidat, 1960) were considered to be species inquirendae possibly conspecific with E. granulosus. In his monograph on the suborder Taeniata, Abuladze (1964) followed an earlier revision (Rausch, 1953) in also recognizing E. felidis and E. lycaontis Ortlepp, 1934. Verster (1965) considered both of the latter to be subspecies of E. granulosus. Some investigators (e.g., Rico, 1961, 1963 ; RomeroTorres and Campbell, 1965) do not accept E. multilocularis as being specifically distinct from E. granulosus. In contrast to this, the morphological and biological peculiarities of E. multilocularis led Abuladze (1960) to establish for it the genus Alveococcus Abuladze, 1960; the designation Alveococcus multilocularis (Leuckart, 1863) has been

(1) Résumé français à la fin de l'article. 
widely accepted by helminthologists in the Soviet Union. The conclusions of Rausch and Nelson (1963) concerning the systematics of these Cestodes are accepted in the present paper. Since E. oligarthrus is so little known, this study has been concerned almost entirely with $E$. granulosus and $E$. multilocularis.

It is the purpose of this paper to discuss briefly the distribution and natural history of E. granulosus and E. multilocularis; to define the developmental and morphological characteristics of these Cestodes in their natural hosts, and to describe some of the variants observed in mammals of the other species; to review criteria that have been used in defining taxa at the infraspecific level, and to consider the validity of the proposed subspecies of Echinococcus spp.

The material studied, mainly collected since 1948, has been obtained from wild and domestic animals, from animals experimentally infected, and from man. Specimens of larvae in situ were fixed in 10 per cent formalin. The fluid-filled cysts of $E$. granulosus were satisfactorily preserved only when injected with a small quantity of undiluted formalin by means of a 27 - or 30 - gauge needle. Standard techniques were applied in the preparation of histological sections. For study of the gross structure of the larval E. multilocularis, sections cut at $1 \mathrm{~mm}$ or less were stained in a 1 per cent aqueous solution of methyl greenpyronin, destained and differentiated in ethanol, dehydrated, cleared in terpineol, and permanently mounted. Distortion of larval membranes in tissues containing early developmental stages of E. granulosus was avoided by staining in methyl green-pyronin and mounting in glycerin jelly.

\section{BIOLOGICAL CHARACTERISTICS OF ECHINOCOCCUS SPECIES}

\section{THE ADULT CESTUDE AND THE FINAL HOST}

Species of Echinococcus require two mammalian hosts for completion of their life cycles. The final host is a carnivore, and under natural conditions (i.e., biotic conditions unmodified by man) the larval Cestode commonly occurs in one or more species of herbivorous mammals upon which the final host is dependent. Thus, the Cestode is adapted to hosts having an essentially obligatory predator-prey relationship.

At higher latitudes, the larval E. granulosus occurs naturally in large ruminants, mainly cervids, and the adult Cestode is found in the wolf, Canis lupus Linnaeus, which regularly preys upon deer. The larval E. granulosus develops slowly in these long-lived intermediate hosts and attains maximum productivity in older individuals. The adult E. multilocularis occurs naturally in foxes of the genera Alopex and Vulpes, and microtine rodents serve as the intermediate host. In contrast to that of $E$. granulosus, the larva of E. multilocularis develops rapidly, becoming infective and attaining maximum productivity of protoscolices within a period of a few months in an intermediate host whose life expectancy does not exceed a year. The life cycle of E. oligarthrus is unknown ; possibly the larval stage occurs in some of the larger South American rodents upon which the feline final hosts are known to prey (Cameron, 1926). 
E. granulosus and E. multilocularis exhibit a relatively high degree of host specificity under natural conditions. Although these Cestodes are segregated ecologically because of the predator-prey relationships of their hosts, such segregation obviously is not absolute; where the two species are sympatric, as is the case over much of the northern hemisphere, the final and intermediate hosts of either species may occasionally be exposed to infection by the appropriate stage of the other. They do not, however, share any intermediate host, and under natural conditions their strobilar stages are known to develop normally in only a single species, the wolf (Rausch, 1958 ; Petrov and Chertkova, 1959 ; Kadenatsii, 1959, cited in Petrov and Delianova, 1962). It is even possible that Cestodes of both species might be found in an individual wolf ; they are able to develop synchronously and coexist in dogs (Rausch, unpublished data).

Through the practice of animal husbandry and the disruption of various ecosystems, man has inadvertently created conditions that often favor the propagation of parasitic helminths such as taeniid Cestodes. The domestic dog replaces the wolf, from which it was derived (Clutton-Brock, 1963), as the final host of E. granulosus, and domestic ungulates replace the wild cervids as intermediate hosts. The requirements of this Cestode are satisfied whenever dogs are maintained in association with domesticated ungulates. Through the dispersal of dogs and other domestic animals, E. granulosus has been introduced into new ecosystems. This has sometimes resulted in the involvement of indigenous faunas in its life cycle. Some examples of host assemblages that serve to perpetuate $E$. granulosus are given below.

Dog-Domestic Ungulate. In many regions of the world where the raising of livestock is a major industry (southern Europe, formerly in Iceland, in much of South America, in New Zealand, Australia, and elsewhere) the life cycle of E. granulosus is completed in dogs and, most commonly, sheep and cattle. Goats, swine, horses, camels, and other species may serve as the intermediate host ; the reindeer is the important domestic species at higher latitudes. This is the most significant type of synanthropic cycle in terms of the total numbers of animals affected. Infection of man is commonplace under such conditions.

Dog-Wild Ungulate. Some of the aboriginal peoples of northern regions derive their livelihood largely from hunting wild ungulates. Deer such as elk (= moose), Alces alces Linnaeus, and wild reindeer ( = caribou in North America), Rangifer tarandus Linnaeus, are killed in large numbers and their viscera are either fed directly to dogs or are discarded in places where they are accessible to dogs. Dogs in rural areas also may become infected when they feed upon viscera of deer killed by sportsmen. Such is the probable source of infection of dogs in the Matanuska region of south-central Alaska, where numerous dogs have been observed feeding on viscera from recently killed elk (R. A. Rausch, personal communication).

Wild Carnivore-Domestic Ungulate. Livestock may be exposed to infection when maintained on rangeland frequented by wild canids or, more rarely, by carnivores belonging to other families. In Australia, the dingo, a dog evidently introduced by aboriginal immigrants (Grassé, 1955), is considered to be an important source of 
infection of cattle (Durie and Riek, 1952). In parts of Africa, wild canids such as the hunting dog, Lycaon pictus Temminck, and the black-backed jackal, Thos (= Canis) mesomelas Schreber, may comprise a source of infection for domestic animals (Nelson and Rausch, 1963 ; Verster, 1965), but probably they are of little importance compared with domestic dogs in the same areas. Infected jackals, Canis aureus Linnaeus, have been reported in the Soviet Union (Sadykhov, 1953 ; Rodonaia, 1951, cited in Petrov and Delianova, 1962) and in Ceylon (Dissanaike and Paramananthan, 1960). E. granulosus has been found also in the North American coyote, Canis latrans Say (Freeman et al., 1961 ; Holmes, 1961). Under certain conditions, still undefined, foxes, Vulpes vulpes Linnaeus and $V$. corsac Linnaeus, may harbor egg-producing Cestodes of this species (Malczewski, 1963 ; Shumakovich and Nikitin, 1959).

Wild Carnivore-Man. In parts of East Africa, high rates of infection with E. granulosus exist in aboriginal peoples having close contact with domestic dogs. Larval Cestodes of human origin presumably account for some infections in hyaenas, Crocuta crocuta (Erxleben), in these regions, since certain peoples expose the dead and dying to these animals, in which development of the adult Cestode is known to take place (Nelson and Rausch, 1963 ; Nelson et al., 1965). Although practices of this kind were more general before various aboriginal cultures had been disrupted by Europeans, it is improbable that man has ever been of importance as an intermediate host of $E$. granulosus.

These examples represent some of the more easily discernible patterns in the transmission of $E$. granulosus; others may be disclosed by further investigation. In some regions of the world, the life cycle of this Cestode has come to involve mammals belonging to groups far removed phylogenetically from the natural hosts. A cycle of this type exists in Australia, for example, where various species of wallabies (Wallabia and Thylogale) serve as the intermediate host. The larval Cestode has been recorded from wild herbivores belonging to several groups, of which few have any importance in perpetuating $E$. granulosus.

The dog also is an important final host of E. multilocularis. The house cat as well has been found to be infected (Ambo et al., 1954) and its capacity to serve as a final host of this Cestode has been confirmed experimentally (Vogel, 1957 ; Petrov and Lukashenko, 1962 ; Rausch, unpublished). Although no domestic animals serve as intermediate host of E. multilocularis, a commensal rodent, the house mouse, Mus musculus Linnaeus, may do so (Vogel, 1960). Vogel observed protoscolices in larvae obtained experimentally in wild house mice, and other investigators have found certain strains of laboratory mice to be susceptible to infection. Strains of wild house mice also can be expected to differ in degree of susceptibility to infection; for example, house mice captured at Anchorage (south-central Alaska) were found difficult to infect, and larvae obtained in a few animals did not produce protoscolices (Rausch, unpublished data). A larval Cestode containing 12 protoscolices was found by Dubinin (1953) in a house mouse trapped at Astrakhan', on the Volga Delta ; although identified as $E$. granulosus, the larva probably was that of $E$. multilocularis.

Dogs become infected when they capture and eat microtine rodents. Cats may become infected in the same manner, or by eating infected house mice (Vogel, 1955). 


\title{
THE GEOGRAPHIC DISTRIBUTION OF ECHINOCOCCUS spp.
}

\author{
1. THE DISTRIBUTION OF E. GRANULOSUS.
}

In the absence of fossil remains, the distributional history of such an organism as E. granulosus can be traced only indirectly, but the sequence of events that has led to involvement of domestic animals in the life cycle of this Cestode can be rather accurately documented. E. granulosus has been dispersed to all parts of the world only comparatively recently.

From his analysis of the upper Pleistocene mammalian fauna of Europe, Zeuner (1958) concluded that no new species is known to have arisen in that region since the Last Interglacial (Riss/Würm), which ended about 150,000 years ago. Because the adaptation of a Cestode to its host involves a long evolutionary process (Baer, 1934, 1946 ; Stunkard, 1957), one can postulate that the helminth fauna of these mammals has remained stable for a comparable period of time. Such a conclusion is supported by zoogeographic evidence for the minimum geologic age of other species of Cestodes occurring in northern mammals ; for example, certain species of Cestodes in rodents must have existed in their present hosts since at least before the beginning of maximum glaciation of Würm time (Rausch, 1957, and unpublished). Thus, the parasite-host relationships of $E$. granulosus could well have been established in their present pattern by the late Pleistocene. Excepting some latitudinal shifts in geographic ranges, the Pleistocene mammalian fauna of Eurasia was to a considerable degree the same as that of Recent time.

Toward the end of the Pleistocene period, as the continental glaciers retreated, the tundra of northern Europe was replaced by a succession of forests which correspondingly restricted the distribution of tundra-inhabiting mammals. As early as the latest phase of the last (Würm) glaciation, about 18,000 years ago, the fauna of central Europe was that characteristic of the boreal forest, with such species as wild swine, Sus scrofa Linnaeus, red deer, Cervus elaphus Linnaeus, elk, Alces alces, roe deer, Capreolus capreolus Linnaeus, and aurochs, Bos primigenius Bojanus (see Zeuner, 1959).

The mesolithic inhabitants of the European forests were primarily hunters, some possessing domestic dogs (= wolf) toward the end of mesolithic time (Charlesworth, 1957 ; Clutton-Brock, 1963). According to Charlesworth (p. 883), the mesolithic peoples of early post-glacial time were succeeded by neolithic invaders whose civilization arose in western Asia and Egypt 7,000-8,000 years ago. These peoples had domestic animals, including sheep and goats. As pointed out by Herre (1963), the chronological order in which animals were domesticated differed from region to region. The wolf was the first species to be domesticated in Europe; the domestic swine was derived from European wild swine; domestic cattle were derived from the aurochs (Charlesworth, 1957 ; Herre, 1963), which became extinct as recently as the early part of the 17th century. Information about the chronology of domestication of animals in the Near East has been summarized by Reed (1960, fig. 7). From the Neolithic through the successive cultures to historical time, the raising of livestock was practiced 
by various peoples of Europe. In the first written account of the Germans, for example, Tacitus (Germania, 98 A.D.) noted that much importance was attached to the keeping of large herds.

Conditions favoring a synanthropic cycle of $E$. granulosus appear thus to have existed in Europe since early Neolithic time, the original wolf-ungulate host assemblage gradually being replaced by (and, until recently, coexisting with) the dog-domestic ungulate assemblage. Ungulates of species that were later domesticated must have served as intermediate hosts of $E$. granulosus under natural conditions; i.e., the adaptation of the parasites to development in these animals had taken place long before the beginnings of domestication. For example, the larval $E$. granulosus is not uncommon at present in wild swine, S. scrofa, in Eurasia (Zakhrialov, 1958 ; Wetzel and Rieck, 1962). With the extirpation of the wolf and with other modifications of the ecosystem, the life cycle of $E$. granulosus came to involve primarily the domesticated animals. Dispersal of this Cestode from western Eurasia has followed introductions of domestic animals to other parts of the world.

At higher latitudes, the cycle of $E$. granulosus involving the reindeer and the wolf persisted from Pleistocene time to the present. Compared with the other species of ungulates, the domestication of the reindeer was accomplished only recently (see Herre, 1955). The wild and domestic forms of Rangifer tarandus differ little morphologically and probably not at all biologically ; they interbreed freely when circumstances permit, and the domesticated animals revert readily to the wild state. Thus, both the wild and domestic reindeer can well serve as intermediate host of E. granulosus throughout the Eurasian tundra, although the wolf has in part been replaced by the dog as final host.

Since the reindeer appears to be one of the species that extended their range eastward and southward from the amphiberingian region during post-Pleistocene time, the same biological form of $E$. granulosus can be expected to have a holarctic distribution at higher latitudes. Macpherson's study (1965) indicated that reindeer also inhabited the periglacial tundra south of the ice during Würm time; since wolves were present, completion of the life cycle of E. granulosus was possible there also. The reindeer was never domesticated by aboriginal peoples in North America, and it was not until the early 20 th century that domestic herds were established by means of animals imported from Eurasia. That the latter are susceptible to infection by the indigenous North American form of E. granulosus is demonstrated by the findings of Choquette et al., (1957).

Other ungulates besides wild reindeer have also long served as the intermediate host of $E$. granulosus at higher latitudes. Both elk and red deer, for example, existed in unglaciated regions of northeastern Siberia and in the amphiberingian region during the late Pleistocene (Vangengeim, 1961; Rausch, 1963 ; Guthrie, 1966). The musk ox, Ovibos moschatus Zimmermann, survived the Pleistocene only in North America. Whether it is frequently a host of the larval E. granulosus is unknown; the single record of infection in this species involved an abnormally developed larva lacking protoscolices (Gibbs and Tener, 1958). 


\section{Dispersal of $E$. granulosus during historical time}

If $E$. granulosus had not been already widely distributed in Asia and North Africa by early historical time, it would have become so as a result of the extensive movements of peoples that began in about the 10 th century. The chronology of probable introductions of this Cestode by means of domestic animals during the period of conquest and colonization of the 17 th and 18 th centuries, however, can be determined fairly well. The present cosmopolitan distribution of E. granulosus is a result of such comparatively recent introductions.

Some records of introductions of domestic animals into regions colonized by Europeans since about 800 A.D. are reviewed below. Sources are not indicated for the information that is readily available from standard reference works on world history.

ICELAND. The colonization of Iceland began about 870 A.D., but immigration declined and apparently ceased after about the year 930. The population of Iceland was derived mainly from Norway, some immigrants coming also from the British Islands (Thorarinsson, 1960). Since domestic animals accompanied the earliest settlers, E. granulosus presumably became established at an early date. Inasmuch as the only terrestrial mammal indigenous to Iceland is the arctic fox (Saemundsson, 1939), which has no part in the life cycle of E. granulosus, the Cestode clearly could not have been indigenous. However, apparently without considering that E. granulosus had been introduced there from western Europe, van Deinse (1957) postulated that infected dogs transported from Iceland to western Europe, North Africa, and the Mediterranean region by whaling ships and other vessels, mainly during the 17 th and 18 th centuries, accounted for the spread of this Cestode in these lands. This untenable hypothesis was first advanced by van Deinse in 1919 (original not seen).

North America. E. granulosus of European origin might have been carried into North America by Norsemen who colonized Newfoundland about 1,000 years ago (Ingstad, 1964). If so, however, the Cestode probably disappeared with the domestic animals a few years later when the colony was deserted. Following a period of exploration, permanent settlements of Europeans were established in eastern North America during the 17 th century. With importation of domestic animals, mainly from France and England, E. granulosus presumably was introduced during the early colonial period; it was not, however, reported until much later. The first published record of hydatid disease of man appears to be that of Low (1822), involving a patient treated during the summer of 1808 . According to Magath (1941), however, no autochthonous case in man was confirmed prior to 1900. The first record of the adult Cestode in the United States was that of Curtice (1892), who found an infected dog in Washington, D. C. The occurrence of the larval Cestode in domestic animals in Canada was reported by Osler (1882), who also referred to data published in 1845 concerning infected swine in Cincinnati, Ohio. Data on rates of infection in cattle, sheep, and swine slaughtered in the United States during the period 1 July 1897-30 June 1899 were published by Salmon (1901). 
That E. granulosus had become widely dispersed in the United States by the late 19 th century is indicated by locality records of specimens of the larval Cestode in the Helminthological Collection of the U.S. National Museum. Specimens with date of collection and recorded origin are as follows : (in swine) Washington, D. C., 1891 ; St.-Louis, Missouri, 1895 ; Cincinnati, Ohio, 1899 ; Ottawa, Iowa, 1895 ; Sioux City, Iowa, 1895 ; Silver Creek, Washington, 1896 ; (in cattle) Indianapolis, Indiana, 1897 ; Chicago, Illinois, 1891. Specimens were collected after 1900 in the following states: New-York, Massachusetts, New Jersey, Maryland, Tennessee, Virginia, Illinois, Kansas, Nebraska, and California. The scarcity of information from earlier years is probably indicative both of a lack of qualified observers and of poor systems of maintaining records, if indeed any were kept at all, rather than of the rarity of the Cestode. Information published more recently on the occurrence of $E$. granulosus in man and domestic animals in the United States has been summarized by Magath (1954), Katz and Pan (1958), and Hutchison (1960).

The existence of a natural cycle of $E$. granulosus involving the indigenous fauna of the boreal forest was discussed by Riley (1933), who found infected wolves and elk in Minnesota. Subsequently the larval Cestode has been reported from wild ungulates over much of northern North America, and the strobilar stage has been found frequently in the wolf. These animals have been regarded as reservoir hosts of the form of E. granulosus that is found in domestic animals farther south in the United States (see Magath, 1954), but there is evidence now to support the conclusion that it is, rather, an indigenous North American form.

Whether E. granulosus was a member of the indigenous fauna of the extensive steppe region of central North America cannot now be determined. Possibly a natural cycle existed involving the bison, Bison bison (Linnaeus), and other ungulates, including the red deer (= wapiti in North America), with the wolf as the final host. Systematic slaughter of the bison was carried out during the period $1830-1888$, the effort being most intense during the years 1870-1883 (Hornaday, 1899). Extermination of the bison as a wild species severely affected its natural predators, both canine and human, and the wolf also was soon extirpated. Evidently no observations were recorded on helminths of bison prior to the time they ceased to exist in the wild state. E. granulosus has been recorded from this mammal by Sweatman and Williams (1963), and a cyst-like formation of uncertain identity, possibly the larval E. granulosus, was reported from a bison by Cameron (1923). This larval Cestode was not found in 20 examined in 1951 in central Alaska, where a herd has been established by introduction, nor was it listed among those helminths found in the closely related and similarly almost extinct European bison, B. bonasus (Linnaeus) in Poland (Dróždž, 1961).

The analysis of the available information supports the conclusion that two forms of E. granulosus exist in North America. These forms, one indigenous and one introduced, are largely allopatric in distribution and differ ecologically and biologically. Their characteristics will be discussed later in the present study.

South America. European colonization of South America began during the first two decades of the 16th century, with the establishment of settlements in the Panama- 
nian region during 1509-1513. Soon thereafter colonies were founded at various places along the eastern coast of the continent. De Mendoza undertook colonization of the mouth of the Río de la Plata in 1535, and Buenos Aires was founded in 1536 . During the next few years settlements were established along the west coast of South America and in what is now México.

The introduction of E. granulosus into South America probably took place before 1550. Pérez Fontana (1949), in his discussion of the origin and spread of this Cestode in South America, indicated that dogs were brought to the Río de la Plata by de Mendoza, and that herds of cattle and sheep were established in the same region between 1536 and 1601 . The Spaniards brought dogs to Peru in 1532, according to Zapatel et al. (1962). The first record of occurrence of E. granulosus in man and cattle in South America was evidently that of Gay (1849; cited in Neghme, 1958). In Uruguay the larval Cestode was noted in cattle in 1880, and in man in 1883 ; in Argentina it was recorded for man between 1860 and 1870, and from cattle in 1875 (Pérez Fontana, 1949).

No indigenous species of Echinococcus is known to have occurred in canine animals in South America, although the status of E. patagonicus Szidat, 1960, described from canids of the genus Dusicyon, remains to be determined (Szidat, 1960; Blood et al., 1963). Domesticated camelids have become involved in the life cycle of E. granulosus in some regions; infected alpacas, Lama pacos Linnaeus, were reported by Santiváñez and Cuba (1949), Roman (1956), and by Zapatel et al. (1962), and infected llamas, Lama glama Linnaeus, by Arnao Mendoza (1951). The larval stage of Echinococcus sp., evidently E. granulosus, has been recorded from other indigenous mammals including rodents of the genera Microcavia and Octodon (de la Barrera, 1948 ; Neghme, 1958 ; Alvarez, 1961).

E. oligarthrus (Diesing, 1863), which may be exclusively a parasite of felids, is known only from South America, having been described from the puma, Felis concolor Linnaeus, from Brazil. Specimens from a jaguarundi, F. yagouaroundi Geoffroy, from the Zoological Garden of London, were studied by Cameron (1926), who pointed out that E. cruzi Brumpt and Joyeux, 1924, described from an agouti, Dasyprocta aguti Linnaeus, from the state of São Paulo, Brazil, may represent the larval stage of E. oligarthrus.

Australia and New Zealand. After discovery of the east coast of Australia by Cook in 1770 , colonization began with the establishment of a penal colony by the British at Port Jackson (Sydney), New South Wales, in 1788. Although domestic animals were brought by the first expedition, the raising of sheep was not undertaken until 1794 (Langer, 1960). E. granulosus could have been introduced from Great Britain during the earliest years of colonization, after which introductions probably were made independently at different places over a period of many years. Dew (1928, p. 40) stated that hydatid disease « ....appeared first soon after the 'fifties, as sheep-raising became general... \$ Infection in man was recognized at least as early as 1860 (Hudson, 1861). By 1900, this Cestode was present throughout the livestock-raising regions of Australia. 
Langer (1960) noted that the raising of sheep in New Zealand was inaugurated during 1843-1844. Before this time, however, various kinds of domestic animals evidently had been introduced; during Cook's third voyage, for example, on 21 February 1777 , aboriginal leaders were presented with a pair of swine and a pair of goats \&...after they had promised not to destroy them. » (King, 1793, p. 51). The inhabitants of New Zealand already possessed dogs (Cook, 1822, p. 77). The government of New Zealand began to issue leases for grazing lands in 1851, after which sheep husbandry became the major industry. Hydatid disease was made notifiable in 1873 (Gemmell, 1958). Foster (1958) estimated that, in relation to the size of the population, hydatid disease in man is more prevalent in New Zealand than in any other country.

In Australia, the indigenous mammals have become involved to a limited degree in the life cycle of E. granulosus (Durie and Riek, 1952). New Zealand had no indigenous terrestrial mammals ; wild ungulates of various species have been introduced comparatively recently from other parts of the world (Wodzicki, 1950), but they appear to have little importance as intermediate hosts of E. granulosus (Sweatman and Williams, 1962).

Other Regions. The sequence of events leading to the establishment of E. granulosus in most other regions can no longer be traced, but introductions no doubt took place during the period of European colonization (from ca. 1600). In the Pacific region, for example, Cook purchased swine, sheep, and buffalo at the island of Savu (= Sawoe) in the Lesser Sunda Islands (Indonesia) on 20th September 1770, observing at the time animals of other species, including goats, horses, dogs, and cats (Cook, 1822, p. 116). Earlier Dutch or Portuguese expeditions probably had introduced some of these domestic animals. E. granulosus was first recorded from Japan by Janson (1893), who observed infected cattle in 1886 and who believed that the Cestode had been introduced from China. Schwartz (1925) and Tubangui (1925) reported the tapeworm from the Philippine Islands.

E. granulosus probably has had a wide distribution in Asia and northern Africa since ancient times, but subsequent introductions must have taken place repeatedly since the beginning of the period of exploration and colonization by Europeans. In Asia it occurs throughout the Soviet Union (where, evidently, as in North America, two forms exist), and has been reported from India, Ceylon, Pakistan, China, and Outer Mongolia. In Africa this Cestode appears to be present wherever the raising of livestock is practiced. The life cycle of E. granulosus involves indigenous wild animals in some regions of both Asia and Africa (Paramananthan and Dissanaike, 1961 ; Nelson and Rausch, 1963 ; Verster, 1965).

Continued international movement of domestic animals can be expected to result in further dispersal of this and other helminths, as the following examples indicate. Cordy and Eastlick (1951) found cysts containing protoscolices in a horse two years after it had been brought from England, where presumably it had become infected; a sheep infected in Australia was taken into Japan (Yamashita, 1956) ; in New York City, adult Cestodes were found in a dog imported from, and presumably infected in Greece (Sterman and Brown, 1959); Karamendin (1963) reported the finding of the larval E. granulosus in cattle imported into the Soviet Union from Outer Mongolia and 
China ; and in 1945, cysts were obtained from the lungs of a horse imported from Belgium to Ohio (U.S.A.) (Rausch, unpublished).

\section{THE DISTRIBUTION OF E. MULTILOCULARIS}

For about a century after identification of the causative agent of alveolar hydatid disease of man by Virchow (1855) and Buhl (1855), the disease was believed to be restricted geographically to central Europe and parts of Russia (Schwarz, 1928 ; Posselt, 1936), although a few isolated cases had been reported from other regions (Dew, 1957). Recognition of $E$. multilocularis as a distinct species stimulated new research, particularly in the Soviet Union, with the result that the parasite-host relationships and geographic distribution of this Cestode have become comparatively well known in less than a decade. Since E. multilocularis is not known to have become established anywhere outside the geographic range of microtine rodents, its distribution may be restricted by the host specificity of the larval stage.

The following review of the geographic distribution of E. multilocularis also includes host records, which have not been completely summarized before. Except on certain islands, E. multilocularis is sympatric with E. granulosus throughout its range.

Central Europe. The first recorded case of alveolar hydatid disease was that of Buhl (1852), who described in detail a condition that he believed at the time to represent the first known case of colloid carcinoma of the liver. Although not stated, the origin of Buhl's first case was evidently southern Germany. By 1881, enough cases had been diagnosed to permit definition of the endemic region as comprising Bayern, Württemberg, and northern Switzerland (Huber, 1881).

As determined from records of the occurrence of human disease, E. multilocularis is now known to be endemic in the region of central and southern Germany, western Austria, Switzerland, and eastern France. In Germany, the disease has been reported mainly from the states of Bayern (particularly Allgäu and Schwaben, in Oberbayern), Baden, and Württemberg (Schwarz, 1928 ; Posse t, 1936). Cases have been recorded in Germany at least as far north as the Harz Mountains (Gruber, 1949), and some are known from Thüringen (Güthert and Giegier, 1959). Alveolar hydatid disease is prevalent in the Schwäbische Alb in Württemberg (Kudlich and Dick, 1960), and it is there that the natural hosts of this Cestode (field vole, Microtus arvalis Pallas, and red fox) were discovered by Vogel (1955). A few cases have been reported from other localities in Germany (Schwarz, 1928), but some of these must represent infections acquired within the main endemic region.

The compilation of cases published by Huber (1881) indicates that alveolar hydatid disease was recorded in Switzerland as early as 1858. Dardel (1927) summarized data on the occurrence of this disease in Switzerland up to 1925, listing 102 cases considered to have been of autochthonous origin. This work was continued by Schmid (1958), who added 89 more for the period 1926-1955. Fifteen additional cases diagnosed in northeastern Switzerland during the period 1959-1963 have been reported by Hedinger and Hardmeier (1964). Although known from all parts of the country, 


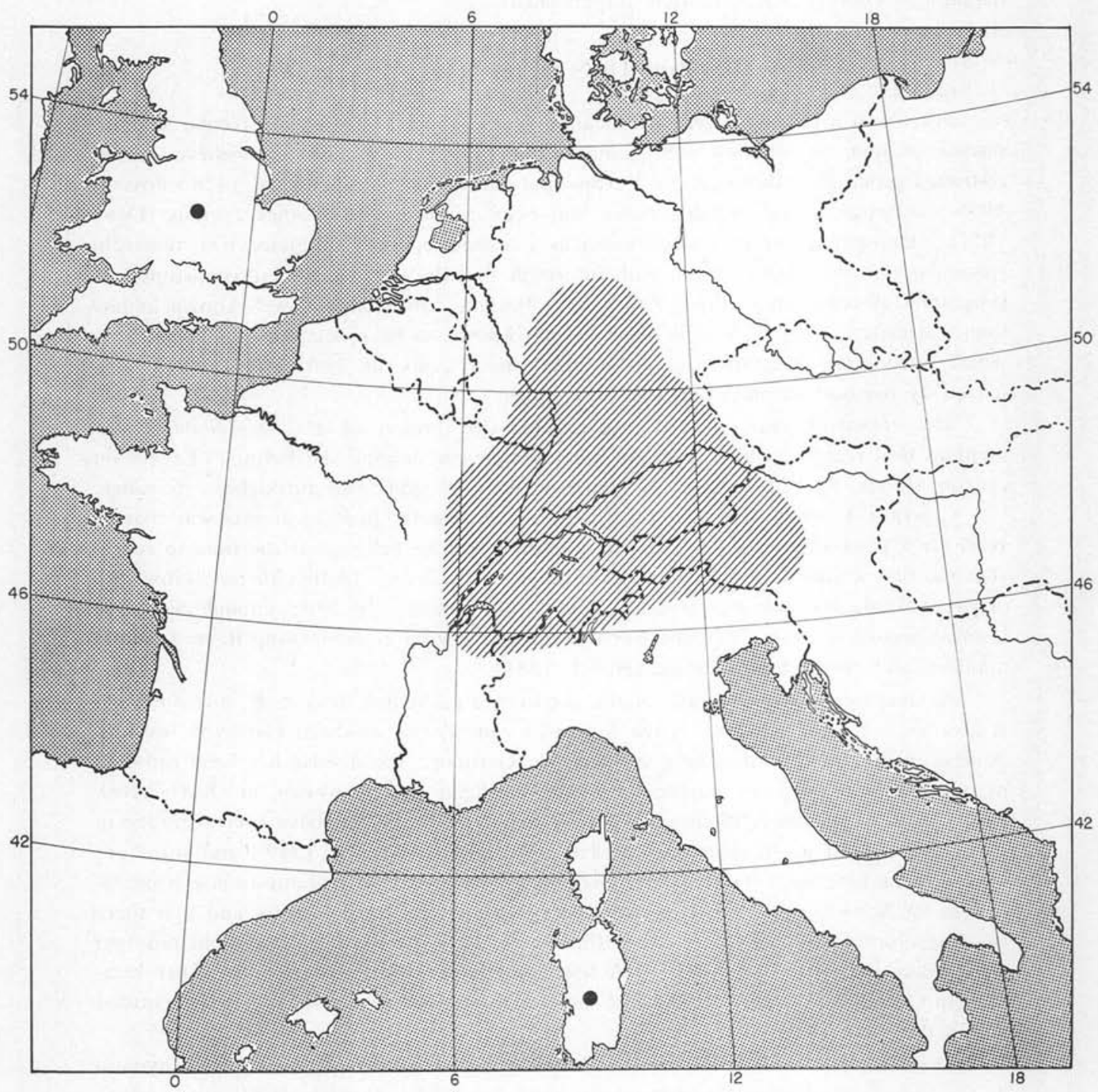

FIG. 1. - The approximate distribution of Echinococcus multilocularis in central Europe (shaded area). The black dots indicate single records of human infection in Great Britain and Sardinia

(Distribution approximative d'Echinococcus multilocularis en Europe centrale (zone hachurée). Les cercles noirs signalent les cas d'infestation humaine en Grande-Bretagne et en Sardaigne) 
alveolar hydatid disease is most prevalent in the northeast, in an area delineated approximately by Zürich - the Bodensee - Schaffhausen; a second area of concentration of cases, in the vicinity of Basel, was considered by Schmid to be a continuation of endemic foci in the Schwarzwald and Vogesen, to the north. Infected red foxes have been found in northern Switzerland by Vogel and Wiesmann (cited in Vogel, 1961). An infected vole, Microtus sp., was found in Switzerland by J. G. Baer (cited in Rausch, 1952).

In Austria, alveolar hydatid disease is most prevalent in Tirol, two endemic foci being in the vicinity of Innsbruck and Kitzbühel respectively; smaller foci exist in Kärnten and Nordsteiermark (Posselt, 1925, 1936).

The first reported case of alveolar hydatid disease of French origin was evidently that studied by Dematteis (1890), involving a patient from Haute-Savoie who entered the Canton Hospital in Geneva in June, 1889. Only four cases had been reported up to 1922, according to Martin and Tisserand (1922). At the present time, however, at least 51 cases are known (Michon et al., 1961). Michon et al. determined that the disease occurs throughout northeastern France ; it is more prevalent in the provinces of Savoie, Haute-Savoie, and Jura, but the endemic region also includes the Vosges, Meuse, and Meurthe-et-Moselle. The adult E. multilocularis has been found in a red fox in Haute-Savoie by Euzéby $(1960 a)$.

Three cases of alveolar hydatid disease were listed by Posselt (1925) as originating in northern Italy, and three others possibly originated there. A case later diagnosed as alveolar hydatid disease by de Lorenzo (1937) involved instead the larval E. granulosus with formation of daughter cysts, according to the published description. Biocca (1956) described a case of alveo'ar hydatid disease in a 52-year-old man born and living on the island of Sardinia, far south of any known endemic region. In a recent review of the status of hydatid disease in Italy, Tasselli (1963) stated that only E. granulosus is present in that country; however, E. multilocularis should be expected to occur at least in that part of Italy contiguous with eastern France (Haute-Savoie and Savoie), Switzerland, and Tirol. There is no evidence thus far that E. multilocularis is endemic in Sardinia.

A fatal case of alveolar hydatid disease has been recorded in Great Britain, in a woman who had never been out of the country (Walshe, 1954). Possibly a dog or cat imported from central Europe was the source of infection; a second hypothesis to be considered is that E. multilocularis is endemic in Great Britain. Heller (1874, p. 304) reported having observed in collections in Great Britain two hepatic specimens tentatively identified by him as characteristic of E. multilocularis infection.

The limits of the endemic region in central Europe as now recognized are shown in Fig. 1.

Fennoscandia. There are no published records of alveolar hydatid disease from the Fennoscandian Peninsula, nor has the adult Cestode been found in red foxes in Finland and Norway. Since infected arctic foxes have been found on Kil'din Island, which lies in the Barents Sea near the coast of the Kola Peninsula (Leikina, 1957), 
E. multilocularis could be expected to occur a.so in arctic foxes on the adjacent mainland. Farther south, in the vicinity of Riga, the larval E. multilocularis has been reported from a red-backed vole, Clethrionomys glareolus Schreber, by Lesin'sh (1959).

TABLE I

Findings in 9.376 MiCROTINE RODENTS IN ALASKA

(OBSERVations faites SUR 9.376 Rongeurs Microtidés en AlasKa)

\begin{tabular}{|c|c|c|c|}
\hline Place of Origin & $\begin{array}{l}\text { Number } \\
\text { Examined }\end{array}$ & $\begin{array}{l}\text { Number } \\
\text { Infected }\end{array}$ & $\begin{array}{l}\text { Per Cent } \\
\text { Infected }\end{array}$ \\
\hline $\begin{array}{l}\text { Arctic Coast } \\
\text { (Including Arctic Slope) .... }\end{array}$ & 1.229 & 0 & - \\
\hline $\begin{array}{l}\text { Seward Peninsula } \\
\text { (Including Kotzebue and } \\
\text { Unalakleet) } \ldots \ldots \ldots \ldots \ldots \ldots\end{array}$ & 85 & 2 & 2 \\
\hline Brooks Range .............. & 573 & 0 & - \\
\hline Lower Kuskokwim Region ... & 87 & 0 & - \\
\hline $\begin{array}{l}\text { Aiaska Peninsula (From King } \\
\text { Salmon River west) .......... }\end{array}$ & 746 & 0 & - \\
\hline $\begin{array}{l}\text { Interior Alaska (Mainly taiga } \\
\text { zone) } \ldots \ldots \ldots \ldots \ldots \ldots \ldots \ldots \ldots\end{array}$ & 1.079 & 0 & - \\
\hline Nunivak Island $\ldots \ldots \ldots \ldots \ldots$ & 94 & 0 & 一 \\
\hline St. Lawrence Island ........ & 5.035 & 895 & 17,7 \\
\hline St. George Island $\ldots \ldots \ldots \ldots$ & 65 & 0 & - \\
\hline St. Matthew Island ......... & 255 & 0 & - \\
\hline Kodiak Island $\ldots \ldots \ldots \ldots \ldots$ & 16 & 0 & - \\
\hline Umnak Island $\ldots \ldots \ldots \ldots \ldots$ & 112 & 0 & - \\
\hline
\end{tabular}

EASTERN Europe. E. multilocularis is not known from eastern European countries. The first and only case of alveolar hydatid disease to be reported from Poland was that of Sowiakowski (1955) ; however, the published description indicates that this record is based upon an infection involving $E$. granulosus with formation of daughter cysts. E. multilocularis has not been reported from natural hosts in Poland. This Cestode has not been found in foxes in Czechoslovakia (Prokopič, 1960 ; Kozman and Schanzel, 1962) ; however, the proximity of the known endemic region suggests that the Cestode might be present in western Czechoslovakia. Two questionable cases of alveolar hydatid disease in Hungary and one in Romania were listed by Posselt (1925). The disease has not been observed in Jugoslavia (Suić, 1951; 1952, p. 71). The report of E. multilocularis from domestic animals in Bosnia by Boko and Gavez (1958) was based upon the multivesicular larva of $E$. granulosus.

Two cases of alveolar hydatid disease have been diagnosed in Bulgaria (Nenow, 1960). This country, contiguous with Turkey on the south, may be part of an endemic region that largely surrounds the Black Sea. 
TURKEY. Alveolar hydatid disease was first diagnosed in Turkey in 1939, according to Oytun (1957), and by 1962 the total of known cases was 29 (Tahsinoglu and Hacihanefioglu, 1962). A rather uniform distribution of cases is illustrated by the map published by the latter authors.

The two species of Microtus, M. socialis Pallas and M. guentheri Danford and Alston, which occur in this region (see Ellerman and Morrison-Scott, 1951) might well serve as the intermediate host of E. multilocularis.

In Turkey also the multivesicuar larva of $E$. granulosus in domestic animals has been confused with that of $E$. multilocularis. Cases involving the former have been reported by Oytun (1957), Yasarol (1960), and by Merdivenci (1962), who published a detailed description of a specimen from the liver of an Indian buffalo, Bubalus bubalus (Linnaeus), an introduced species widely established in the Near East.

The Soviet UnION. Investigation of the occurrence and ecology of E. multilocularis was initiated in the Soviet Union soon after the specific identity of this Cestode had been established. Identification of $E$. multilocularis in hosts other than man was first reported by Petrov (1957), who, according to Petrov and Delianova (1962), studied materials preserved in the Central Helminthological Museum of the Skriabin AllUnion Institute of Helminthology (vIGIS), and by Gagarin et al., (1957), who examined material from rodents preserved in the collections of the Academy of Sciences of the Kirgiz SSR. Later in the same year, Leikina (1957) reviewed the existing information about hydatid disease in the Soviet Union, publishing records of the adult and larval stages of E. multilocularis in natural hosts. Data on the occurrence of the adult Cestode have been compiled recently by Petrov and Delianova (1962), and records of cases of alveolar hydatid disease have been summarized by Bregadze and Konstantinov (1963).

Volokh (1957, p. 78) credited Boettcher (1858) with the first published record of alveolar hydatid disease in what is now the Soviet Union. The material studied by Boettcher consisted of a preserved liver from the collection at the university in Dorpat (= Tartu) in Estonia. Vierordt (1886) listed 84 cases of alveolar hydatid disease, of which only four were of Russian origin, but by 1925, Posselt compiled records on as many as 134 cases from Russia. The endemic foci in the Soviet Union were defined by Posselt (1936) as the territory around Moscow, the Volga region (centering about Kazan'), and the regions around Tomsk and Irkutsk in Siberia. Believing the multivesicular form of the larval E. granulosus in the liver of cattle to be of the same species as that affecting man, Posselt suggested that the Cestode might have been introduced into Russia by means of cattle imported from the endemic region of central Europe. He considered the most important endemic focus of the disease to be the area around Kazan', where German immigrants had settled. In 1959, Leikina (p. 542) listed the regions in which alveolar hydatid disease was known as follows: Tomsk Oblast', Kazakh SSR, Bashkir ASSR, Tatar ASSR, Irkutsk, Omsk, and Novosibirsk districts, Iakutsk ASSR, Altai Krai, the Middle Volga, Ukraine SSR, and the Azerbaidzhan SSR.

Subsequent investigations by Soviet helminthologists have shown that E. multilocularis is found throughout the greater part of the territory of the Soviet Union, as 
outlined below. Place-names and the present boundaries of political units are taken from Atlas SSSR (Glavnoe Upravlenie Geodezii i Kartografii, MVD SSSR, Moscow, 1955). The biotic divisions in the Soviet Union to which reference is made in this paper are as defined by Rikhter (1961). When only common names were provided for rodents reported as intermediate hosts of $E$. multilocularis, corresponding scientific names have been determined from the monograph by Vinogradov and Gromov (1952).

The western limits of the geographic range of $E$. multilocularis within the Soviet Union are uncertain. The northernmost record in the west is that from the vicinity of Riga, mentioned above. Alveolar hydatid disease is known from the Belorussian SSR (Abuladze, 1964) and the Ukraine (Pod'iapol'skaia and Kapustin, 1958, p. 219), although Bregadze and Konstantinov included no data for these regions in their study (1963). Merkusheva (1958, cited in Leikina et al., 1959) found the larval Cestode in the striped field mouse, Apodemus agrarius Pallas, in the Belorussian SSR. Shul'man (1958), reviewing the helminths affecting man in the Ukraine, did not include E. multilocularis. The study of parasites of dogs and cats in the Kiev region by Chebotarev et al. (1961) did not reveal it, nor was the larval stage found by Sharpilo (1961) in rodents in the Ukraine. Alveolar hydatid disease is known from the Moldavian SSR (Abuladze, 1964), which is contiguous with the Ukraine on the south. Of the five cases of alveolar hydatid disease recorded in North America outside Alaska, two were diagnosed in patients who had immigrated from the western Ukraine.

Published data indicate that E. multilocularis occurs throughout the extensive steppe to the north and east of the Black Sea. Infections in man are known from the Rostov Oblast', and from Georgia, Armenia, and Azerbaidzhan (Bregadze and Konstantinov, 1963). The adult Cestode has been found in dogs and red foxes in Dagestan (Iarulin, 1958 ; Nikitin, 1959, 1960, $1962 a, 1962 b$ ). Data on alveolar hydatid disease in the Azerbaidzhan SSR have been published by Mamedov (1964), who in a survey of rodents also found the larval cestode in the jerboa, Allactaga elater Lichtenstein. Kurashvili $(1961,1962)$ reported the larval Cestode from voles, Microtus socialis, and the adult from foxes in Georgia. Two cases of alveolar hydatid disease were reported by Ansimov (1960) from the Checheno-Ingush ASSR (included as a part of the Dages$\tan$ ASSR in Atlas SSSR, 1955). Although aiveolar hydatid disease has been recognized in Armenia only in recent years, 18 cases had been diagnosed by 1963 (Martikian, 1963).

Within the zone of semi-desert around the northern end of the Caspian Sea, alveolar hydatid disease is known from the Astrakhan' Oblast' (Abuladze, 1964). The larval stage of Echinococcus sp., possibly that of E. multilocularis, found by Dubinin (1953) in the liver of a house mouse in the delta of the Volga has been mentioned above. Infection in man has been reported also from Gur'ev, on the Caspian Sea in the western part of the Kazakh SSR (Bregadze and Konstantinov, 1963).

In the remainder of the European part of the Soviet Union (not considering the tundra zone, which is discussed below), the distribution of E. multilocularis may be discontinuous. Alveolar hydatid disease has long been known from the region around Moscow. Farther east, it has been recorded from the Ivanov and Gor'kov districts 
(Abuladze, 1964), and the adult Cestode has been found in red foxes in the latter region by Romanov $(1962,1964)$. Data on the disease in man in the Kirov Oblast' have been summarized recently by Protasova (1965). To the south, alveolar hydatid disease has been recorded from the Voronezh Oblast' (Abuladze, 1964), and from the Middle Volga region, including the Tatar ASSR and the Kuibyshev Oblast' (Petukhov, 1957; Dotsenko and Diiigenskaia, 1959 ; Bregadze and Konstantinov, 1963), as well as from the Bashkir ASSR (Pod'iapol'skaia and Kapustin, 1958, p. 219) and the Orenburg Oblast' [designated Chkalov Obl. in Atlas SSSR, 1955] (Bregadze and Konstantinov, 1963).

In the southern Ural region, alveolar hydatid disease occurs in the Cheliabinsk Oblast' (Bregadze and Konstantinov, 1963). Salamatin (1958, cited in Leikina et al., 1959) found the larval Cestode in muskrats, Ondatra zibethicus (Linnaeus), and the adult in red foxes in this region. In the contiguous Kurgansk Oblast', larval Cestodes identified as E. granulosus were collected from muskrats by Spasskii et al. (1951) and by Lavrov (1953); the actual species in these cases was probably $E$. multilocularis. Kondrat'ev (1962) obtained the adult E. multilocularis from red foxes and from a dog in the Kurgansk Oblast'.

E. multilocularis is widely distributed in the Kazakh SSR. Infections in man have been reported from North Kazakhstan and East Kazakhstan (Bregadze and Konstantinov, 1963) ; from the Pavlodar Oblast' (Pantiukhov, 1962) ; from the Karagandinsk Oblast' (Sokolov, 1954) ; and from South Kazakhstan (Arslanova, 1960). The adult Cestode has been found in red foxes in the Akmolinsk Oblast' (Kadyrov, 1959), and in the region of Lake Alakol' in the Alma-Atinsk Oblast' (Arslanova, 1962). An infected dog was reported from the Semipalatinsk Oblast' by Vibe (1961). The larval Cestode has been found in muskrats in the Kzyl-Ordinsk Oblast' (Spasskii et al., 1951) (identified as E. granulosus); in the vicinity of Lake Alakol' (Ramazanov, 1963; Arslanova, 1962) ; in the vicinity of Lake Balkhash (Arslanova, 1962); and from the Alma-Atinsk Oblast' (Zikeeva and Arslanova, 1961). As early as 1953, the macroscopic and microscopic characteristics of the larval E. multilocularis in the liver and other organs of a muskrat were described by Vsevolodov (1953). Along the Emba River, in the Aktiubinsk Oblast', Chun-siun and Alekseev (1960) found the larval Cestode in the great gerbil, Rhombomys opimus Lichtenstein.

Farther south, E. multilocularis was first reported in Uzbekistan by Sadykov (1963), who found the adult Cestode in a red fox and in a dog. Petrov and Delianova (1962) reported an infected dog from the Turkmen SSR. Alveolar hydatid disease is known from the Tadzhik SSR (Zhavoronkov, 1962), and the adult Cestode has been recorded there from the corsac fox, Vulpes corsac Linnaeus (Petrov and Delianova, 1962). In Kirgiz SSR, this Cestode was first reported by Gagarin et al. (1957) from the narrowskulled vole, Microtus gregalis Pallas. A survey of the parasites of rodents by Tokobaev $(1959,1960)$ disclosed the larval Cestode in $M$. gregalis as well as in the northern mole-vole, Ellobius talpinus Pallas.

Immediately adjacent to the Soviet Union on the south, northern Iran and northern Afghanistan probably come within the range of this Cestode. Although alveolar hydatid disease has not been recorded in Iran, the finding of larval cestodes of the genus 
Echinococcus in « rongeurs qui sont les hôtes favorables...» (Alavi and Maghami, 1964, p. 77) indicates that E. multilocularis is present. Dr. A. Rafyi, Faculty of Veterinary Medicine, University of Tehran, kindly provided the information that the infected rodents included house mouse, short-tailed mole rat, Nesokia indica Gray and Hardwicke, and a gerbil, Meriones sp. Lehmensick (1964) did not find this Cestode in the course of his preliminary investigations in Afghanistan.

Numerous cases of alveolar hydatid disease have been recorded in western Siberia, particularly in the Omsk Oblast' (Bregadze and Konstantinov, 1963). Pautov (1964) reported on 29 cases found at autopsy in the city of Omsk during the period 19411962 , and data on cases diagnosed throughout the Oblast' during the period 1958-1960 were summarized by Miroshnikova (1964). Kadenatsii and Gerasimova (1958) found the larval Cestode in muskrats in this region. In material presumably preserved, from the Trans-Ural and Ob' River regions, Petrov (in Petrov and Chertkova, 1959) determined the presence of the larval Cestode in the following species of rodents : muskrat ; Ob' lemming, Lemmus obensis Brants ( $=$ L. sibiricus Kerr) ; northern vole, Microtus oeconomus Pallas; narrow-skulled vole, $M$. gregalis major Ognev. A high rate of infection of red foxes with Echinococcus sp. (? E. multilocularis) was reported by Kadenatsii (1953), whom Petrov and Delianova (1962) cited as having reported in 1959 and 1960 the finding of E. multilocularis in dogs and wolves from the Omsk Oblast'.

Information concerning the northern part of the Omsk Oblast' will be considered below with the tundra zone as a whole.

Alveolar hydatid disease is relatively common in the Novosibirsk Oblast' and in the Altai Krai, to the south (Bregadze and Konstantinov, 1963). In areas where E. granulosus and E. multilocularis are sympatric, man is usually infected more often by $E$. granulosus; in the Novosibirsk Oblast', 60 cases out of 88 treated surgically were found to be the alveolar type of disease (F. F. Bogdanov, 1959). Bogdanov considered infection in man to be more prevalent in this region than the data indicate, since surveys of the total population had never been taken. In the same oblast', Leikina et al. (1959) found the larval Cestode in the muskrat and northern vole in the Barabinsk region, and in both the northern vole and the northern red-backed vole, Clethrionomys rutilus Pallas, in the Maslianinsk region. Within the central Barabinsk forest-steppe, Lukashenko and Zorikhina (1961) discovered infections in rodents of five species : common field vole, Microtus arvalis Pallas ; muskrat ; northern vole; northern red-backed vole; narrow-skulled vole. Besides these, vesicles lacking protoscolices, possibly anomalous larvae of E. multilocularis, were found in the lungs of the Norway rat, Rattus norvegicus Berkenhout, and in the liver of the striped hamster, Cricetulus barabensis Pallas. They also recorded the adult Cestode from one dog and one wolf, and from numerous red foxes taken in 5 districts of the Barabinsk forest-steppe.

E. multilocularis occurs throughout Eastern Siberia, where the disease in man is widespread (Bregadze and Konstantinov, 1963). K.F. Bogdanov (1959) stated that although E. multilocularis is present throughout the Krasnoiarsk Krai, alveolar hydatid disease is seen most often in peasants living in the southern regions of the Krai, inclu- 
ding the Khakassk Autonomous Oblast'. Mamedov (1960) reported six cases of alveolar hydatid disease in patients from the Turukhansk region, in the north-central part of the Krai, and found the adult Cestode in a dog and in arctic foxes there also. Among rodents examined, Mamedov found the larval Cestode in the northern vole only. From the Tuvinsk ASSR [incorporated with the Krasnoiarsk Krai as the Tuvinsk Autonomous Oblast' in Atlas SSSR, 1955], contiguous with Outer Mongolia on the south, Sulimov (1963) has reported the larvae from the northern vole and from the Daurian pika, Ochotona daurica Pallas. Echinococcus sp., presumably E. multilocularis, was found commonly in red foxes in the same region by Sulimov (1959; cited in Petrov and Delianova, 1962). In the Irkutsk Oblast', contiguous with the Krasnoiarsk Krai to the southeast, alveolar hydatid disease has long been recognized in the human population, but the Cestode evidently has not been recorded from mammals of other species. The cestode identified as E. granulosus by Machul'skii (1949; cited in Spasskii et al., 1952) from the Daurian red fox in Buriat-Mongolia was later determined to have been E. multilocularis (Machul'skii, 1958) ; Machul'skii also reported the larval Cestode from the long-tailed suslik, Citellus undulatus Pallas, and from the Mongolian gerbil, Meriones unguiculatus Milne-Edwards, in Buriat-Mongolia. Alveolar hydatid disease is rare in the Buriat-Mongol'sk ASSR (Bregadze and Semenov, 1961).

Semenov (1960) considered alveolar hydatid disease to be a major health problem in the Iakutsk ASSR, which, with an area in excess of a million square miles, is the largest political division of the Soviet Union. Iakutia ranks first among the various regions of Siberia in numbers of cases (Bregadze and Konstantinov, 1963). During only a brief period (November, 1963-January, 1964), Alekseeva (1965) was able to study 72 cases of hepatic infection originating in the Viliuisk district of southwestern Iakutia. (Papers pertaining to the occurrence of $E$. multilocularis have been published in Iakutia by Safronov during the period 1955 to 1961 , but these have been unavailable). Data on this Cestode in animals other than man have been provided in a comprehensive study by Gubanov (1964). E. multilocularis has been reported from all of the five regions of Iakutia defined by Gubanov (p. 150): Southern, Central, Northwest, Verkhoiansk, and Kolymo-Indigirsk. The adult Cestode has been found in the arctic fox and in the red fox, and Safronov (1961, cited in Gubanov, 1964) reported it from dogs. Gubanov indicated that the larval Cestode has been found in Iakutia in rodents of the following species: Ob' lemming ; narrow-skulled vole; northern redbacked vole; North Siberian vole, Microtus hyperboreus Vinogradov; squirrel, Sciurus vulgaris Linnaeus. No records of $E$. multilocularis or alveolar hydatid disease from the region south of the Iakutsk ASSR and east of the Buriat-Mongol'sk ASSR (Chitinsk Oblast' and Amursk Oblast') appear to exist.

E. multilocularis occurs widely in the Soviet Far East, which includes the Primorsk Krai, the Khabarovsk Krai, and the Magadansk Oblast'. The Cestode has not been recorded from the Primorsk Krai, nor was it mentioned in the review of helminths of this region by Oshmarin (1963). In the western portion of the Khabarovsk Krai, during a 3-year period (1957-1959), 3 patients were treated for alveolar hydatid disease 
in the surgical clinic in Khabarovsk (Bregadze and Semenov, 1961). The adult Cestode was found in red foxes in Kamchatka, in the northern part of the Krai, by Kozlov (1961). Four cases of alveolar hydatid disease were recorded in Chukchi patients in the Magadansk Oblast' by Bregadze and Semenov (1961), and 50 cases diagnosed in the city of Magadan during the period 1954-1962 were reported by Ivchenko (1963). The adult Cestode was reported from arctic foxes from the Chukotsk Peninsula by Ovsiukova (1963) and by Kozlov et al. (1963).

Throughout the Eurasian tundra zone, including the arctic islands, E. multilocularis seems to occur wherever the arctic fox is found. Its presence in arctic foxes on Kil'din Island (Leikina, 1957), near the western limits of the tundra zone, indicates its probable occurrence in the Murmansk Oblast', and perhaps as well in northernmost Finland and Norway, where the arctic fox is quite restricted in distribution (Siivonen, 1956 , p. 180 ; Johnsen, 1947 , p. 319 ). In this region, the Norwegian lemming, Lemmus lemmus Linnaeus, could serve as the intermediate host, since these rodents are susceptible to infection (Rausch, unpublished data). Chirkova et al. (1958) reported the adult cestode in arctic foxes from the vicinity of Kara, on the Baidaratsk Gulf, and the lower Pechora River, both in the Arkhangel'sk Oblast'. In this region also, infected foxes were found by Sorochenko (1964). Petrov (1941; cited in Petrov and Delianova, 1962) recorded E. multilocularis in arctic foxes from the Obdorsk Tundra and from Novaia Zemlia. Data on the occurrence of this Cestode in arctic foxes on the Iamal Peninsula were published in a series of papers by Luzhkov $(1960,1963 a$, $1963^{\circ} b, 1963 c$ ), and Kopein (1958 ; cited in Luzhkov, $1963 b$ ) found the larval Cestode in the Ob' lemming and in the narrow-skulled vole. E. multilocularis was also recorded from arctic foxes on the Iamal Peninsula by Lukashenko and Brzheskii (1963), and it was found in the same host on the Taimyr Peninsula (Petrov and Delianova, 1962). The findings of Gubanov (1964) in the Kolymo-Indigirsk region of Iakutia have been cited above; a case of alveolar hydatid disease in a patient from the vicinity of Nizhne-Kolymsk, on the lower Kolyma River, was described by Semenov (1954). Records from the Chukotsk Peninsula have been cited above (Ovsiukova, 1963; Kozlov et al., 1963), and four cases of alveolar hydatid disease reported from the Magadansk Oblast' by Bregadze and Semenov (1961), originating at Port Providenie at the easternmost tip of Siberia, presumably involved Chukchis living in the tundra zone.

There are no published data on the occurrence of E. multilocularis on the Soviet arctic islands lying east of Novaia Zemlia (i.e., Severnaia Zemlia, Novosibirsk Islands, and Wrangell Island). To the extreme east, near the Siberian coast, lies St. Lawrence Island; findings there can be considered more conveniently in the section concerning North America, below. The Commander Islands, in the Bering Sea east of Kamchatka, are of unusual interest, for it was there that the larval E. multilocularis (designated E. granulosus) was first recorded from a natural intermediate host. Infected redbacked voles, C. rutilus, were found on Bering Island by Barabash-Nikiforov (1938) ; the adult Cestode was reported from arctic foxes on the same island by Afanas'ev (1941). However, even earlier, the finding of the larval Cestode had been reported by 


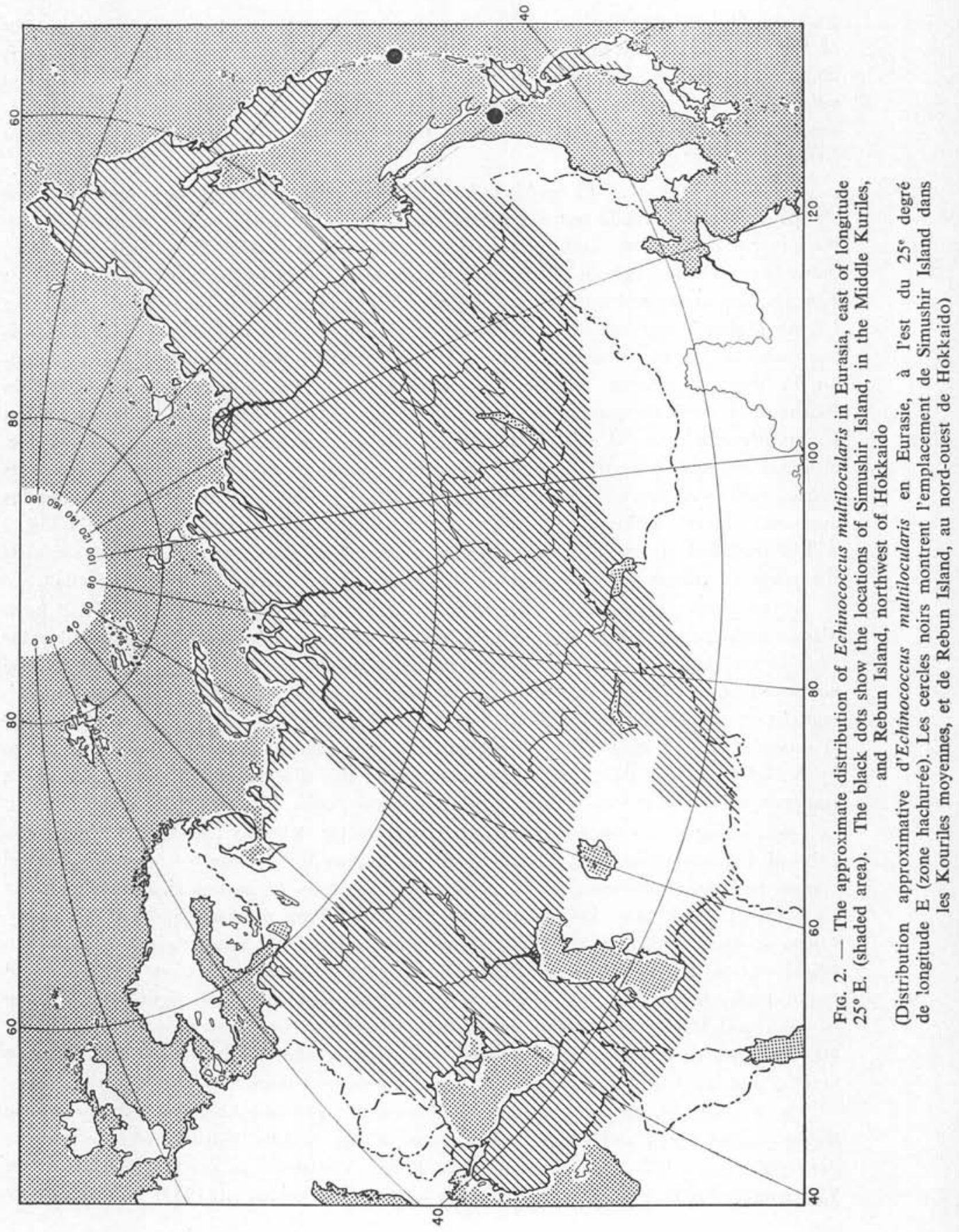


Iogansen (Johansen) (1934, p. 257) in connection with observations made on the diet of the snowy owl, Nyctea scandiaca (Linnaeus), on Bering Island. E. multilocularis apparently became established on Bering Island with the introduction of red-backed voles from the Eurasian mainland (Stejneger, 1884 ; Barabash-Nikiforov, 1943 ; Johansen, 1950). On Copper Island, where there are no voles, the Cestode is absent (Afanas'ev, 1941).

The distribution of E. multilocularis in the Soviet Union, as now understood, is shown in Fig. 2. While more accurate than a map published earlier (Rausch, 1958), the present delineation must be considered only approximate. E. multilocularis probably is present throughout Siberia, but the southern limits of its distribution in eastern Eurasia are undetermined. It can be expected to occur in China, in the Sinkiang Uighur region in the northwest and in Heilungkiang in the northeast. E. multilocularis must also be present in northern Outer Mongolia, where the mammalian fauna is similar to that of adjacent Siberia. Alveolar hydatid disease was not mentioned in Ivashkin's (1955) compilation on the helminths of Outer Mongolia, however. That E. multilocularis would exist in the desert east of the Black Sea seems improbable, although predator-prey relationships and other conditions may be such as to ensure its propagation even there. The distribution of this Cestode west of the Ural Mountains appears to be discontinuous, and the western boundary of its range as shown in Fig. 2 will be modified as new information becomes available. However, all evidence supports the present concept that the endemic region of central Europe is indeed disjunct.

JAPAN AND THE KURILE IsLANDS. About 70 cases of hydatid disease had been diagnosed in Japan before 1956, and at least 30 of these infections were of the alveolar type (Yamashita, 1956). On Rebun Island, situated in the Sea of Japan off the northwest coast of Hokkaido, alveolar hydatid disease is especially prevalent, the estimated rate of infection being about 1 per cent of a population of approximately 10,000 (Yamashita et al., 1955). Several papers have been published in the Japanese language by $\mathrm{K}$. Ichikawa, H. Iida, and others, concerning this disease on Rebun Island, and a comprehensive report was issued by the Hokkaido Public Health Center in 1956.

According to a summary kindly prepared by Dr. Kimiho Ichikawa, Chief of the Clinical Pathology Section, Tonan Hospital, Sapporo, 51 cases of alveolar hydatid disease had been diagnosed in Japan through the study of pathological specimens by mid-1962. Those cases known prior to 1961 have been reported by Ichikawa (Jour. Japanese Assoc. Inf. Dis. 35, 1961). Twenty-nine of the 51 cases originated on Rebun Island during the period 1937-1962. Ten cases were in patients from other parts of Japan during the period 1921-1960; two were from Hokkaido, and eight from Niigata, Aomori, and Miyagi Prefectures in northern Honshû. Nine patients were believed by Dr. Ichikawa to have become infected while they resided in the Kurile Islands or in Siberia, and no data were available on the origin of two cases.

It has been concluded that $E$. multilocularis probably became established on Rebun Island when red foxes from islands in the Middle Kuriles were introduced during the years 1924-1926 (Inukai et al., 1955; Yamashita et al., 1955 ; Rausch and Yamashita, 1957). Infection in man was first recognized in 1937, approximately 
TABLE II

Findings in 2.638 CANine animals in Alaska

(ObServations faites SUR 2.638 Canidés en Alaska)

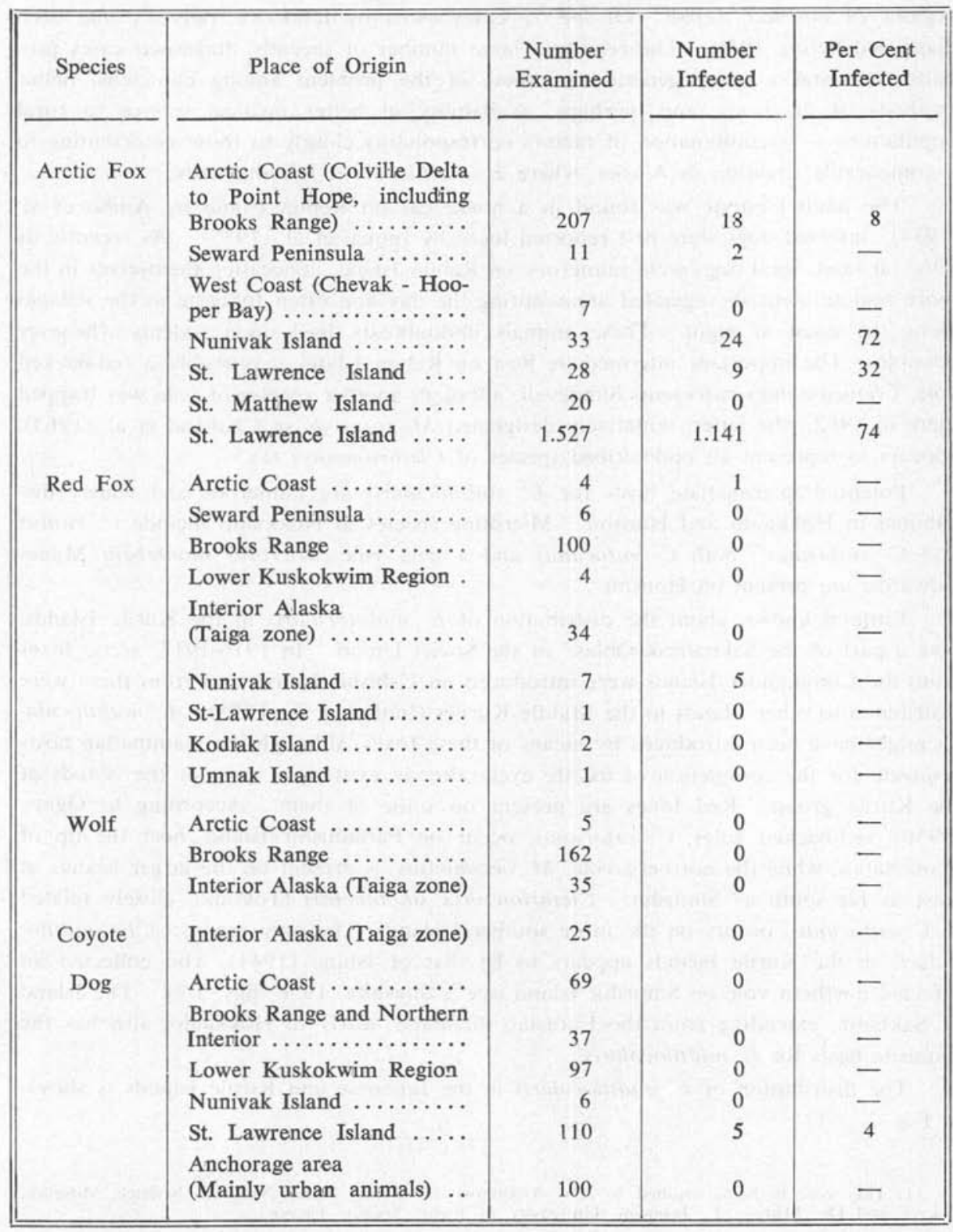


10 years after introduction of the foxes. However, in a series of 10 cases considered by Ichikawa to represent infections acquired elsewhere in Japan, two from Miyagi Prefecture, Honshû Island, were diagnosed in 1921 and 1925. Apparently, therefore, either an earlier introduction had taken place or the Cestode is indigenous in some regions of northern Japan. Of the 51 cases listed by Ichikawa, only 11 had been diagnosed before 1950 . The relatively large number of recently diagnosed cases probably indicates a more general awareness of the problem among clinicians, better methods of diagnosis, and, perhaps, availability of better medical service to rural populations - a combination of factors corresponding closely to those contributing to a comparable situation in Alaska, where E. multilocularis is indigenous.

The adult Cestode was found in a house cat on Rebun Island by Ambo et al. (1954) ; infected dogs were first reported there by Inukai et al. (1955). As recently as 1962 , at least, feral dogs were numerous on Rebun Island, concealing themselves in the more remote, densely vegetated areas during the day and often foraging in the villages along the coast at night. These animals undoubtedly feed upon rodents whenever possible. The important intermediate host on Rebun Island is probably a red-backed vole, Clethrionomys rufocanus Sundevall, although another species of vole was trapped there in 1962 ; the latter, tentatively designated Microtus sp. in Chabaud et al. (1963), appears to represent an undescribed species of Clethrionomys (1).

Potential intermediate hosts for E. multilocularis are numerous and widely distributed in Hokkaido and Honshû. Microtine species in Hokkaido include C. rutilus and $C$. rufocanus; both $C$. rufocanus and a field vole, Microtus montebelli MilneEdwards, are present on Honshû.

Little is known about the distribution of E. multilocularis in the Kurile Islands, now a part of the Sakhalinsk Oblast' of the Soviet Union. In 1916-1917, arctic foxes from the Commander Islands were introduced on Ushishir Island, and from there were distributed to other islands in the Middle Kuriles (Inukai et al., 1955). E. multilocularis might have been introduced by means of these foxes, although the mammalian hosts requisite for the completion of its life cycle already existed on most of the islands of the Kurile group. Red foxes are present on some of them. According to Ognev (1950), red-backed voles, C. rufocanus, occur on Paramushir Island, near the tip of Kamchatka, while the northern vole, $M$. oeconomus, is present on the larger islands at least as far south as Simushir. Clethrionomys sikotanensis (Tokuda), closely related to $C$. rufocanus, occurs on the more southern islands. The only record of E. multilocularis in the Kurile Islands appears to be that of Ishino (1941), who collected an infected northern vole on Simushir Island (see Yamashita, 1956, figs. 5-7). The Island of Sakhalin, extending from the Eurasian mainland nearly to Hokkaido, also has the requisite hosts for $E$. multilocularis.

The distribution of E. multilocularis in the Japanese and Kurile Islands is shown in Fig. 2.

(1) This vole is being studied by Dr. Yoshinori Imaizumi, Japan National Science Museum, Tokyo, and Dr. Murray L. Johnson, University of Puget Sound, Tacoma. 
NoRth America. In the course of a survey of helminths of microtine rodents begun in Alaska in 1949, the larval stage of E. multilocularis was found in northern (tundra) voles on St. Lawrence Island by E. L. Schiller in 1950. At first erroneously identified as E. granulosus by Rausch and Schiller (1951), the Cestode was later recognized to be a distinct species, for which the name $E$. sibiricensis Rausch and Schiller, 1954, was proposed. Reference has been made above to the investigations of Vogel $(1955,1957)$, through which the identity of E. multilocularis was finally established. Thomas and Babero (1956) recommended that the name E. sibiricensis be suppressed, not indicating what they believed to be the valid designation. The Cestode from St. Lawrence Island was assigned the name E. alveolaris (Klemm, 1883) by Mankau $(1956 a, 1956 b, 1957)$. That the latter name was not applied in a formal sense by Klemm (1883) is clearly evident from his conclusions, concerning the identity of the Cestode specifically referred to as E. multilocularis (p. 465).

The adult tapeworm has been recorded on St. Lawrence Island from arctic foxes (Rausch and Schiller, 1951, 1956; Thomas et al., 1954) and from dogs (Rausch and Schiller, 1956). The larval stage has been found in four of the five species of small mammals occurring on St. Lawrence Island: northern vole and northern red-backed vole (Rausch and Schiller, 1951; Thomas et al., 1954); ground squirrel (=longtailed suslik), Citellus undulatus (Pallas), (Thomas et al., 1954); shrew, Sorex jacksoni Merriam (? = S. tundrensis Merriam) (Thomas et al., 1954 ; Rausch, 1958). Eight cases of alveolar hydatid disease have been confirmed in Eskimos from St. Lawrence Island.

St. Lawrence Island lies about 38 miles $(61 \mathrm{~km})$ from the Chukotsk Peninsula, and about 100 miles $(160 \mathrm{~km})$ from the nearest point in Alaska, of which it is politically a part. Although the indigenous mammals, excepting the arctic fox, exhibit some morphological divergence, they are considered to be conspecific with mammals having extensive geographic distributions in both Eurasia and North America. There is evidence that foxes make their way to St. Lawrence Island from one or the other of the two continents (Rausch, $1953 \mathrm{~b}$ ), and helminths having life cycles that cannot be completed on St. Lawrence Island have been found there in arctic foxes. The presumed immigration of foxes from Eurasia provided the basis for the hypothesis that E. multilocularis might have been introduced by this means to St. Lawrence Island, which at the time was believed to represent the easternmost limit of the geographic range of this Cestode (Rausch and Schiller, 1956). Investigations subsequently have shown this concept to be erroneous ; $E$. multilocularis has been recorded from other islands in the Bering Sea and from some of the Canadian arctic islands. Its distribution on the North American continent may prove to be extensive.

One case of alveolar hydatid disease has been confirmed in an Eskimo from Little Diomede Island, in the Bering Strait; this infection probably was acquired on the mainland, where the patient spent many summers, since there appear to be no microtine rodents on Little Diomede Island (J. J. Burns, personal communication). The adult E. multilocularis has been found in red foxes and arctic foxes on Nunivak Island (Rausch, 1956, and unpublished), where the intermediate host is presumably the brown 


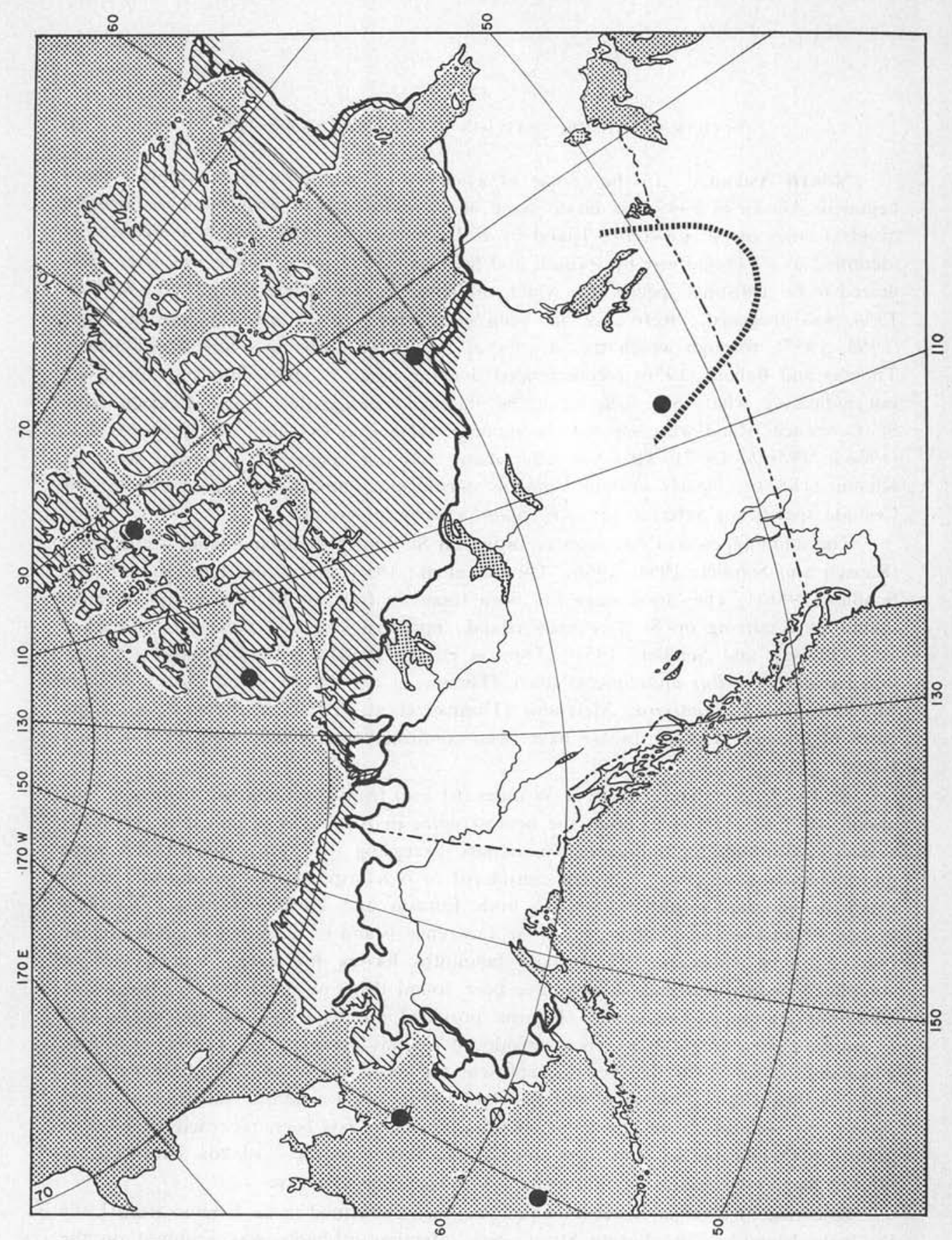

FIG. 3. - The approximate distribution of Echinococcus multilocularis in North America. Shaded areas represent the geographic range of the arctic fox, within which all arctic and subarctic records of this Cestode have originated. The solid line delineates the approximate limits of the tundra zone. The black dots indicate, from left to right, the Pribilof Islands, St. Lawrence Island, Banks Island, Cornwallis Island, and Eskimo Point. The dotted line delimits the known distribution of this Cestode in central North America, the black dot showing the location of Saskatoon, Saskatchewan

(Distribution approximative d'Echinococcus multilocularis en Amérique du Nord. Les zones hachurées montrent la répartition géographique du Renard arctique d'où sont originaires tous les cas arctiques et subarctiques publiés se rapportant à ce Cestode. La ligne épaisse et continue délimite la zone approximative de la toundra. Les cercles noirs indiquent, de gauche à droite, la situation des Iles Pribilof, de 1'Ile St. Laurent, de Banks Island, de Cornwallis Island et d'Esquimo Point. La ligne pointillée montre la distribution déjà connue de ce Cestode au Centre de l'Amérique du Nord. Le cercle noir situe Saskatoon, dans le Saskatchewan) 
lemming (conspecific with the Eurasian Ob' lemming). Investigations on St. Matthew Island, where the arctic fox and a vole, Microtus abbreviatus Miller, are the only terrestrial mammals, have not disclosed the occurrence of $E$. multilocularis. Arctic foxes are present on the Pribilof Islands, where the only other terrestrial mammals found are the brown lemming (St. George Island) and a shrew, Sorex pribilofensis Merriam (St. Paul Island). E. multilocularis was reported from arctic foxes from St. George Island by Fay and Williamson (1962). The shrew on St. Paul Island is presumably susceptible to infection, but the degree to which it is preyed upon by foxes has not been determined. Cases of alveolar hydatid disease have been diagnosed clinically, although not yet confirmed, in Aleut residents of both islands (2).

On the Alaskan mainland, the adult Cestode has been found in both red and arctic foxes at Point Barrow, and in arctic foxes at other localities along the Arctic Coast; an infected arctic fox was trapped also near the edge of the Brooks Range north of Anaktuvuk Pass (Rausch, 1956, and unpublished). The larval Cestode has been recorded on the mainland only from northern voles collected at Wales, on the Seward Peninsula. Nine cases of alveolar hydatid disease have been confirmed in Eskimos from the settlements of Point Hope, Wales, and Kotzebue, all of which are situated along the coast of northwestern Alaska. Thus, all mainland records of E. multilocularis in Alaska have originated within the tundra zone (Fig. 3).

Rates of infection in the natural hosts, both intermediate and final, are influenced by the numerical densities of these mammals as well as by the kind of predator-prey relationship existing between them. Fluctuations in numbers of microtine rodents, usually with a periodicity of 3 to 4 years, with consequent fluctuations in the numbers of arctic foxes, are characteristic in the tundra zone. The productivity of the arctic fox depends upon the availability of microtine rodents during the warmer months; when rodents are abundant, they are utilized almost exclusively as food by the foxes. Thereby results a predator-prey relationship favoring completion of the life cycle of certain taeniid Cestodes, including E. multilocularis. However, it appears that rates of infection in both the intermediate and final hosts approach their highest levels only when the numbers of rodents remain at or above a certain minimal density over periods of some years : i.e., when a more or less obligatory predator-prey relationship is sustained, rather than intermittent. For example, we have observed the highest rates of infection in the natural hosts of E. multilocularis on St. Lawrence Island, where the numbers of voles (M. oeconomus) and foxes do not fluctuate greatly (Fay and Rausch, unpublished data). In contrast, we have found no infected rodents along the Arctic Coast, where the brown lemmings fluctuate extremely in numbers with a periodicity of 3 to 4 years, usually becoming very scarce after only a few months of high density ; rates there in foxes are also comparatively low.

During the time of our investigations (1949-1966), microtine rodents and red foxes in the taiga zone have not been known to attain numerical densities approaching those

(2) After completion of this paper, Mr. R. L. Delong, Pacific Program, Smithsonian Institution, Washington, D.C., kindly made available an infected brown lemming collected by him on 24 July 1966 on St. George Island. 
observed on the tundra. Regardiess of their numerical status, foxes in the biotically more complex taiga are able to feed upon a variety of animals, with the result that predator-prey relationships are much less restricted. E. multilocularis possibly exists in the forested interior of Alaska and has been overlooked because of its infrequent occurrence and because of inadequate sampling.

The numbers and distribution of microtine rodents and canine animals examined by us in Alaska are summarized in Tables I and II, respectively. All microtine species are included, without regard for differences in degree of susceptibility to infection. The rodents are summarized by species in Table III.

For the remainder of North America, knowledge of the helminth fauna is so inadequate as to make largely conjectural any statement about the distribution of $E$. multilocularis. In the Canadian Arctic, the Cestode has been found in arctic foxes on Banks Island and Cornwallis Island; infected foxes have been recorded on the mainland only at Eskimo Point, on the western shore of Hudson Bay, Northwest Territories (Choquette et al., 1962).

These records and the findings in Eurasia and Alaska suggest that E. multilocularis occurs throughout the holarctic tundra zone as a parasite of the arctic fox. As shown by Macpherson (1965, figs. 1 and 4), the range of this mammal in North America is restricted essentially to the tundra zone and the arctic islands. Arctic foxes are occasionally found beyond the limits of the tundra, particularly in winters following severe reductions in numbers of microtine rodents. Records of such wandering animals evidently provided the basis for the more extensive geographic range of the arctic fox as defined by Hall and Kelson (1959, p. 854). In the central Brooks Range, for example, a few arctic foxes are usually trapped by the Eskimos in winters following severe decrease in the numbers of brown lemmings along the Arctic Coast; such an animal provided the southernmost reccrd of $E$. multilocularis in northern Alaska (Rausch, 1956). The approximate distribution of the arctic fox in Alaska is shown in Fig. 3.

TABLE III

Microtine RODENTS EXAMINEd IN ALASKa

(RONGeurs Microtidés examinés en Alaska)

\begin{tabular}{|c|c|}
\hline Species & Number Examined \\
\hline Microtus aconomus ...... & 6.352 \\
\hline 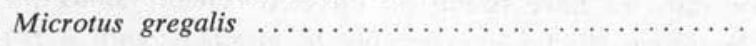 & 381 \\
\hline Microtus pennsylvanicus $\ldots \ldots \ldots \ldots \ldots \ldots \ldots \ldots \ldots$ & 86 \\
\hline 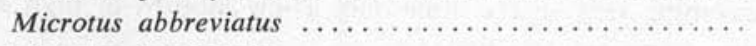 & 255 \\
\hline Microtus longicaudus ..................... & 12 \\
\hline Microtus xanthognathus . .................. & 7 \\
\hline 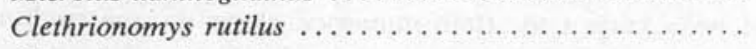 & 686 \\
\hline 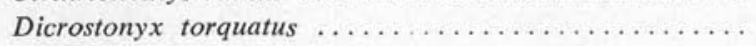 & 182 \\
\hline 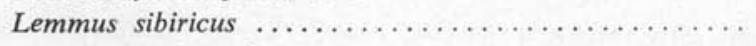 & 1.360 \\
\hline 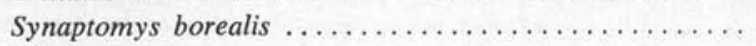 & 18 \\
\hline 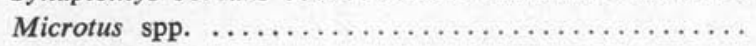 & 37 \\
\hline
\end{tabular}


That E. multilocularis occurs much farther south in North America has been confirmed only recently by Leiby and O'sen (1964), who discovered the adult Cestode in red foxes in North Dakota. The larval stage has been found in the meadow vole, Microtus pennsylvanicus Ord, and in the white-footed mouse, Peromyscus maniculatus (Wagner), by Leiby (1965) and by S. H. Richards, North Dakota Game and Fish Department, Bismarck (unpublished data). Findings in a large series of red foxes examined by Rausch and Richards indicate that the Cestode is widely established in North Dakota.

In 1965, an infected meadow vole was collected near Saskatoon, Saskatchewan, by Hnatiuk (1966). James and Boyd (1937) described a fatal case of alveolar hydatid disease in a 54-year-old man who had immigrated from Iceland to Manitoba at the age of 7. Since alveolar hydatid disease has never been recorded in Iceland, it seems probable, as suggested by West et al., (1963), that this infection was autochthonous. There is thus an increasing amount of information to support the conclusion that E. multilocularis occurs over a comparatively large area in central North America (Fig. 3). All records of this Cestode from natural hosts have originated within the northern part of the extensive region of steppe that extends through the central United States and into southern Canada. E. multilocularis has not been found below the latitude of southern North Dakota. The report by Magath (1965) of the larval stage from the liver of a beef cow slaughtered in Iowa was based upon the typical multivesicular larva of E. granulosus. According to Ohno et al., (1963), the larval stage of Echinococcus sp. was found in the liver of voles, Microtus oregoni (Bachman), in western Oregon; since no details were published, confirmation of this identification is required.

The endemic focus in central North America may be disjunct and therefore perhaps comparable with that in central Europe, or it may represent the southern extremity of a geographic distribution extending uninterruptedly from the tundra zone. High rates of infection in the natural hosts indicate that the tundra and steppe biomes provide optimum conditions for the completion of the life cycle of E. multilocularis. The intervening taiga may comprise an ecological barrier between them, or, again, the rates of infection in the natural hosts in the boreal forest may be so low that the Cestode has escaped detection. That the endemic focus in central North America has resulted from the relatively recent introduction of $E$. multilocularis, perhaps by means of imported dogs, is a possibility as well.

Diagnosis of alveolar hydatid disease is often difficult, even in major endemic regions where clinicians are experienced (cf. Schmid, 1958, p. 78; Iablokov, 1959, p. 538). It is therefore possible that cases of the disease in man in the north-central United States and southern Canada have been overlooked. In addition to the case reported by James and Boyd (1937), at least four others, presumably infections acquired in Europe, have been diagnosed in North America (Dean, 1877 ; Weinberg, 1947 ; Geddes Smith and Hanson, 1961 ; Lafond et al., 1963). Dean also reported a typical lesion in the liver of a Negro woman in St. Louis in 1869 ; this infection could only have been autochthonous. 
GREENLAND. E. multilocularis has not been recorded from Greenland, nor is there evidence that its life cycle could be completed on the island. One species of microtine rodent, a collared lemming, Dicrostonyx torquatus groenlandicus (Traill), which may not be susceptible to infection by the larval Cestode, occurs in northern and eastern Greenland. Arctic foxes periodically make their way in some numbers from the Canadian arctic islands to western Greenland (Braestrup, 1941) and might be expected occasionally to harbor the adult Cestode. E. multilocularis was not found in 17 arctic foxes killed in western Greenland during November, 1965 (F. H. Fay, unpublished data). Beyond the work of Fay, there appears to be no information available on helminths from foxes on this island.

OTHER Regions. Alveolar hydatid disease has rarely been diagnosed outside the known endemic regions. The cases from Great Britain and Sardinia have been mentioned. Single cases have been reported respectively from Australia (Dew, 1931), Argentina (Dévé, 1932), Uruguay (Dévé et al., 1936), and New Zealand (Meade and Barnett, 1941).

The identity of the Cestode involved in the cases from Great Britain and Sardinia seems to have been reliably determined. Whether the remaining four infections were caused by $E$. multilocularis is uncertain ; some, at least, may have been anomalous larvae of $E$. granulosus comparable perhaps to the multivesicular form frequently seen in domestic animals. These four cases and that described by James and Boyd (see Dévé, 1939), were considered by Dévé and Dew to provide evidence in favor of their view that alveolar hydatid disease is caused by the larval E. granulosus. While the significance of the long-standing controversy about the identity of these Cestodes has been lost, the origin of these infections cannot be explained. In connection with the South American cases, Szidat (1963) advanced the hypothesis that E. patagonicus, which has been found in foxes of the genus Dusicyon in Argentina, may cause an alveolar type of hydatid disease in man. The life cycle and ecology of E. patagonicus remain to be investigated.

\section{Summary}

Echinococcus granulosus (Batsch, 1786) and E. multilocularis Leuckart, 1863 [syn. Alveococcus multilocularis (Leuckart, 1863) Abuladze, 1960] are distinguished by well defined biological and developmental characteristics. Obligatory predator-prey relationships of the hosts segregate the two species ecologically under natural conditions. The larval stage of E. granulosus develops slowly in long-lived ungulates, while that of $E$. multilocularis becomes infective within a few months in intermediate hosts (rodents) having a life expectancy of less than a year.

Existing parasite-host relationships of these Cestodes had become established at least as early as late Pleistocene time, and two biologically distinct forms of $E$. granulosus can be defined: one, involving cervids as the intermediate host, has a holaretic distribution at higher latitudes, and the second is adapted to species of mammals of which many have been domesticated. The distributional history of the latter form, 
widely introduced to other parts of the world from Eurasia, has been traced since the time of colonization of Iceland (ca. 870 A.D.).

Apparently restricted by host requirements, E. multilocularis is limited distributionally to the northern hemisphere. Its known range includes the endemic region of central Europe, Bulgaria, Turkey, the Soviet Union east of about Long. $25^{\circ}$ E., and certain islands, including the Middle Kuriles and some of the Japanese islands. In North America the known range of E. multilocularis at high latitudes corresponds closely to that of the arctic fox, Alopex lagopus L. The extent of the recently discovered endemic region in central North America has not been determined.

Published host-records for E. multilocularis have been included, along with a summary of findings in canine animals and rodents in Alaska. Developmental characteristics of the larval stage of these Cestodes will be defined in subsequent sections of this paper.

\section{Résumé}

Echinococcus granulosus (Batsch, 1786) et E. multilocularis Leuckart, 1863 [Syn. Alveococcus multilocularis (Leuckart, 1863) Abduladze, 1960] se distinguent par des caractères biologiques et évolutifs bien définis.

Dans les conditions naturelles, les liens obligatoires qui se sont noués, chez les hôtes, entre les prédateurs et leurs proies ont opéré une ségrégation écologique entre les deux espèces.

Le stade larvaire d'E. granulosus évolue lentement chez des Ongulés à grande longévité ; tandis que le stade larvaire d'E. multilocularis devient infestant en quelques mois chez des hôtes intermédiaires (Rongeurs) dont l'espérance de vie n'atteint pas une année.

Des rapports stables entre le parasite et l'hôte se sont instaurés chez ces Cestodes dès la fin du Pléistocène, et deux formes biologiquement distinctes d'E. granulosus peuvent dès lors être définies : l'une impliquant les Cervidés comme hôtes intermédiaires, et dont la distribution géographique est holoarctique à de hautes latitudes; l'autre qui s'est adaptée à des espèces de Mammifères parmi lesquelles beaucoup sont devenues domestiques, et dont on peut suivre la progression géographique de l'Eurasie vers d'autres parties du monde, depuis l'époque de la colonisation de l'Islande ( $c a .870$ A.D.).

Apparemment limité par les exigences de l'hôte, E. multilocularis s'est cantonné géographiquement dans l'hémisphère Nord. Son aire connue de distribution inclut les régions endémiques d'Europe centrale, de Bulgarie, de Turquie, et d'Union Soviétique à l'Est du méridien $25^{\circ}$, ainsi que diverses îles comprenant les moyennes Kouriles et quelques îles du Japon. En Amérique du Nord, l'aire de répartition connue d'E. multilocularis se maintient à des latitudes élevées et correspond étroitement à celle du renard arctique, Alopex lagopus L. L'étendue du foyer endémique récemment découvert au centre de l'Amérique du Nord n'a pas été déterminée. 
Les hôtes d'E. multilocularis mentionnés dans la littérature sont rapportés ici, ainsi que les observations faites par l'auteur sur des Canidés ou des Rongeurs en Alaska dont les résultats sont résumés dans trois tableaux.

Les caractéristiques du développement des stades larvaires de ces Cestodes feront l'objet d'une étude ultérieure.

\section{Références citées}

Abuladze (K. I.), 1960. - K voprosu o klassifikatsii teniat. Nauch. Konf. posviashch. 40-let. Moskovsk. Vet. Akad., pp. 66-70.

-, 1964. - Teniaty - lentochnye gel'minty zhivotnykh i cheloveka i vyzyvaemye imi zabolevaniia. Osnovy tsestodologii, 4, Akad. Nauk SSSR, Moscow. 530 p.

Afanas'ev (V. P.), 1941. - Parazitofauna promyslovykh mlekopitaiushchikh Komandorskikh Ostrovov. Uchenye zapiski Leningrad Gosudarst. Univ., Ser. biol. Nauk, vyp., 18, pp. 93-117.

Alavi (A.) and Maghami (G.), 1964. - L'echinococcose hydatidose en Iran. Arch. Inst. Razi, $16: 76-81$.

Alekseeva (M. I.), 1965. - Izmenenie belkov i belkovykh kompleksov syvorotki krovi pri al'veoliarnom ekhinokokkoze pecheni (Po materialam ekspeditsii v Iakutskuiu ASSR). Med. Parazit. i Parazit. Bolezni, 34: 396-403.

Alvarez B. (V.), 1961. - Investigaciones sobre echinococcosis silvestre en Chile. Nota preliminar. Biologica, $31: 89-94$.

Ambo (H.), Ichikawa (K.), Iida (H.) and AbE (N.), 1954. - [On echinococcosis alveolaris, endemic parasitosis in Rebun Island.] (In Japanese.) Spec. Rept. Hokkaido Inst. Publ. Health, 4 : 1-19.

Ansimov (A.F.), 1960. - Rasprostranenie i lechenie ekhinokokka v Checheno-Ingushskoi ASSR. Sovetsk. Med., $25: 80-84$.

Arnao Mendoza (M.), 1951. - Parásitos identificados en el Instituto Nacional de Biología Animal, 1946-1951. Rev. Inst. Nac. Biol. Animal, 2: 76-81.

Arslanova (A. Kh.), 1960. - Al'veoliarnyi ekhinokokkoz v iuzhnoi zone Kazakhstana (po sektsionnomu materialu). Med. Parazit. i Parazit. Bolezni, 29: 349-350.

—, 1962. - Enzooticheskii ochag al'veoliarnogo ekhinokokkoza v Alma-Atinskoi Oblasti. Med. Parasit. i Parazit. Bolezni, 31 : 88-91.

BAER (J.-G.), 1934. - L'adaptation des helminthes à leurs hôtes. Bull. Soc. neuchât. Sci. nat., 58 : 57-76.

—, 1946. - I. Les helminthes parasites des vertébrés. Relations phylogéniques entre leur évolution et celle de leurs hôtes. Conséquences biologiques et médicales. Premier Colloque franco-suisse. Parasitologie, Besançon. pp. 1-26.

BARABASH-Nikiforov (I.), 1938. - Mammals of the Commander Islands and the surrounding sea. J. Mammal., 19: 423-429.

-, 1943. - O myshevidnykh gryzunakh (sem. Muridae) Komandorskikh Ostrovov. Zool. Zhur., 22 : 53-54. 
Brocca (P.), 1956. - Considerazioni su di un caso di echinococcosi alveolare del fegato. Rassegna Med. Sarda, 58: 153-173.

BLOod (B. D.), LeLIJVELd (J. L.) and LORD (R. D.), 1963. - Nota preliminar sobre equinococosis en el zorro gris pampeano Dusicyon gymnocercus. Bol. Ofic. Sanit. Panam., $54: 127$.

Boettcher (A.), 1858. - Beitrag zur Frage über den Gallertkrebs der Leber. Archiv. $f$. pathol. Anat., $15: 352-363$.

BogdANOv (F. F.), 1959. - K rasprostraneniiu ekhinokokkoza v Novosibirskoi Oblasti. pp. 550-554. In Trudy Vsesibirsk. Konf. Terap., Revmatizm i parazitarnye zabolevaniia, 13-18 May 1958, Minist. zdravookhran. RSFSR, Novosibirsk. 616 p.

Bogdanov (K. F.), 1959. - Ekhinokokkoz v Krasnoiarskom Krae. pp. 545-550. In Trudy Vsesibirsk. Konf. Terap., Revmatizm i parazitarnye zabolevaniia, 13-18 May 1958, Minist. zdravookhran. RSFSR, Novosibirsk., 616 p.

BoKo (F.) and GAvez (E.), 1958. - O nalazima alveolarnog ehinokoka u Bosni. Vet. Glasnik, 12 : 259-265.

Braestrup (F. W.), 1941. - A study on the arctic fox in Greenland. Immigrations, fluctuations in numbers based mainly on trading statistics. Medd. om Grønland, 131: 1-101.

BREgADZE (I. L.) and KonStantinov (V. M.), 1963. - Al'veoliarnyi ekhinokokkoz (al'veokokkoz). Gosudarst. Izdat. Med. Lit., Moscow., 223 p.

- and Semenov (V.S.), 1961. - Nozogeografiia al'veoliarnoi formy ekhinkokkoza v Sibiri. Med. Parazit. i Parazit. Bolezni, 30 : 168-172.

BuHL, 1852. - Alveolarcolloid in der Leber. Rubner's Illus. med. Zeit., 1: 102-122.

-, 1855. - Ueber die zusammengesetzte Echinokokkengeschwulst der Leber. Verhandl. phys.-med. Gesellsch. Würzburg, $6:$ 428-429.

CAMeron (A. E), 1923, - Notes on buffalo : anatomy, pathological conditions, and parasites. Vet. J., 79:331-336.

CAmeron (T. W. M.), 1926. - Observations on the genus Echinococcus Rudolphi, 1801. J. Helminth., 4 : 13-22.

Chabaud (A. G.), Rausch (R. L.) and Desset (M.-Cl.), 1963. - Nématodes parasites de rongeurs et insectivores japonais. Bull. Soc. Zool. France, 88 : 489-512.

CHARLESWORTH (J. K.), 1957. - The Quaternary Era with special reference to its glaciation, Vol. 2, Edward Arnold, London, pp. 595-1700.

Chebotarev (R. S.), Zaskind (L. N.), Seraia (V. G.) and Pavlova (L. F.), 1961. - K izucheniiu parazitofauny i parazitozov domashnikh plotoiadnykh na territorii Kieva i ego okrestnostei, pp. 188-196. In Problemy parazitologii, Trudy Ukrain. Respub. Nauch. Obshchestva Parazit., No 1, Kiev. 367 p.

Chirkova (A. F.), Romanova (N. P.) and Shmal'gauzen (V. I.), 1958. - K epidemiologii al' veoliarnogo ekinokokkoza v zone tundr evropeiskoi chasti SSSR. Med. Parazit. $i$ Parazit. Bolezni, 27 : 150-152.

Choquette (L. P. E.), Macpherson (A. H.) and Cousineau (J. G.), 1962. - Note on the occurrence of Echinococcus multilocularis Leuckart, 1863 in the arctic fox in Canada. Canad. J. Zool., 40: 1167. 
-, Whitten (L. K.), Rankin (G.) and SeAL (C. M.), 1957. - Notes on parasites found in reindeer (Rangifer tarandus) in Canada. Canad. J. Comp. Med., 21: 199-203.

Chun-Siun (F.) and Alekseev (V. K.), 1960. - Al'veoliarnyi ekhinokokk u bol'shoi peschanki (Rhombomys opimus Licht.) v Kazakhstane. Med. Parazit. i Parazit. Bolezni, 29: 482 .

Clutton-Brock (J.), 1963. - The origins of the dog, pp. 269-274. In Science in archaeology. A comprehensive survey of progress and research, D. Brothwell and E. Higgs, Eds. Basic Books, Inc., New York, 595 p.

CooK (J.), 1822. - Voyages round the world performed by Captain James Cook, F.R.S. by royal authority, containing the whole of his discoveries in geography, navigation, astronomy \& $c$, J. Robins and Co., London, 798 p.

CoRdy (D. R.) and EAstLick (M. G.), 1951. - A report of Echinococcus granulosus in a horse in the state of Washington. J. Parasit., $37: 318$.

CURTICE (C.), 1892. - Parasites. Being a list of those infesting the domesticated animals and man in the United States. J. Comp. Med. and Vet. Arch., 13: 223-236.

DARDEL (G.), 1927. - Das Blasenwurmleiden in der Schweiz, speziell seine Verbreitung beim Mensch und Vieh und das Verhältnis von Echinococcus alveolaris zu hydatidosus, A. Francke Verlag, Bern., 105 p.

DeAn (D. V.), 1877. - Echinococcus multilocularis of the liver. St-Louis Med. and Surg. J., 14 : $420-424$.

De la Barrera (J. M.), 1948. - Echinococcus Granulosus en Microcavia Australis. Arch. Intl. Hidat., 7 : 175-176.

De Lorenzo (F.), 1937. - Un caso di echinococco multiloculare del fegato. Gazz. Osped. Clin., 58: 631-633.

Dematteis (S.), 1890. - Contribution à l'étude des kystes à échinocoques multiloculaires du foie, Diss. Univ. Genève, 78 p.

Dévé (F.), 1932. — L'échinococcose alvéolaire. Prensa Méd. Argentina, 19 : 966-976.

-, 1939. - Une récente observation Islando-Canadienne venant appuyer la doctrine de l'unité de l'échinococcose. Ann. Anat. path. med. Chir. 16: 53-62.

-, Piaggio-Blanco (R.) and García-Capurro (F.), 1936. - Echinococcose hépatique maligne micro-polykystique infiltrante. Forme intermédiaire entre l'échinococcose hydatique et l'échinococcose alvéolaire. Arch. Uruguayos Med. Cirurg. Espec., 8: 3-28.

DEW (H. R.), 1928. - Hydatid disease. Its pathology, diagnosis and treatment, Australasian Med. Publ. Co., Ltd., Sydney, 429 p.

-, 1931. - Echinococcus alveolaris, with report of an Australian case. Austral. and New Zealand J. Surg., 1: 115-141.

—, 1957. - Morphological variation in hydatid disease. Brit. J. Surg., 45 : 447-453.

Dissanaike (A.S.) and Paramananthan (D. C.), 1960. - On the occurrence of Echinococcus granulosus (Batsch, 1786) in a Ceylon jackal. Ceylon Vet. J., 8: 82-87.

Dotsenko (T. K.) and Diligenskaia (A. V.), 1959. - O rabote Kuibyshevskogo otdeleniia vsesoiuznogo obshchestva gel'mintologov (VOG). Med. Parazit. i Parazit. Bolezni, 28 : 753-754. 
DRóžDž (J.), 1961. - A study on helminths and helminthiases in bison, Bison bonasus (L.) in Poland. Acta Parasit. Polonica, 9 : 55-96.

Dubinin (V. B.), 1953. - Parazitofauna myshevidnykh gryzunov i ee izmeneniia $v$ del'te Volgi. Parazit. Sb. Zool. Inst., Akad. Nauk SSSR, 15 : 252-301.

DURIE (P. H.) and RIEK (R.F.) 1952. - The role of the dingo and wallaby in the infestation of cattle with hydatids [Echinococcus granulosus (Batsch, 1786) Rudolphi, 1805] in Queensland. Austral. Vet. J., $28: 249-254$.

Ellerman (J. R.) and Morrison-Scott (T. C.S.), 1951. - Checklist of Palaearctic and Indian Mammals 1758 to 1946, Brit. Mus. (Nat. Hist.), London, 810 p.

EuZÉBY (J.), 1960. - A propos de l'échinococcose larvaire. Données nouvelles concernant la forme alvéolaire de l'échinococcose. Existence d'un foyer savoyard de la maladie. Rev. Hyg. et Méd. soc., $8: 428-438$.

FAY (F. H.) and Williamson (F. S. L.), 1962. - Studies on the helminth fauna of Alaska. XXXIX. Echinococcus multilocularis Leuckart, 1863, and other helminths of foxes on the Pribilof Islands. Canad. J. Zool., 40: 767-772.

Foster (F. H.), 1958. - Hydatid disease in New Zealand. New Zealand Med. J., 57 : $562-$ 571.

Freeman (R. S.), Adorjan (A.) and Pimlott (D. H.), 1961. - Cestodes of wolves, coyotes, and coyote-dog hybrids in Ontario. Canad. J. Zool., 39 : 527-532.

Gagarin (V. G.), Steshenko (V. M.) and Tokobaev (M. M.), 1957. - Rol' gryzunov v rasprostranenii gel'mintozoonozov. Trudy Inst. Zool. i Parazit., Akad. Nauk. Kirgiz. SSR, $6: 159-160$.

Geddes Smith (E. M.) and Hanson (S.), 1961. - Alveolar echinococcosis. A case report with a discussion of ecology of the disease. Amer. J. Clin. Path., 35:160-165.

Gemmell (M. A.), 1958. - Cestode problems of domestic animals and man in the South Island of New Zealand. New Zealand Med. J., 57 : 442-458.

GibBs (H. C.) and TENeR (J.S.), 1958. - On some helminth parasites collected from the musk ox (Ovibos moschatus) in the Thelon Game Sanctuary, Northwest Territories. Canad. J. Zool., 36: 529-532.

Grassé (P.-P.), 1955. - Ordre des Fissipèdes (Fissipeda Blumenbach, 1791). In Traité de zoologie. Anatomie, systématique biologie. Vol. 17. Mammifères, Pt. 1. 1170 p.

GRUBer (G. B.), 1949. - Zum Vorkommen des Echinococcus alveolaris im nördlichen Deutschland. Zbl. f. allgem. Path. u. path. Anat., 84 : 417-420.

GUBANOv (N. M.), 1964. - Gel'mintofauna promyslovykh mlekopitaiushchikh lakutii. Sibir. Otdelenie, Iakutsk. Filial, Akad. Nauk SSSR. Nauka, Moscow, 164 p.

GüTHERT (H.) and GIEGLER (I.), 1959. - Neue Beobachtungen von alveolärem Echinokokkus in Thüringen. Zbl. f. allgem. Path. u. path. Anat., 99 : 515-522.

GuTHRIE (R. D.), 1966. - The extinct wapiti of Alaska and Yukon Territory. Canad. J. Zool., 44 : 47-57.

Hall (E. R.) and Kelson (K. R.), 1959. - The mammals of North America. Vol. 2. Ronald Press, New York, pp. 547-1083. 
Hedinger (C.) and Hardmeier (T.), 1964. - Erschreckende Häufigkeit der Echinokokkenkrankheit in der Nordostschweiz. Schweiz. med. Wochenschr., 94: 1621-1624.

Heller (A. L. G.), 1874. - Invasions-Krankheiten. In Ziemssen, Handbuch d. spec. Path. u. Ther. $3:$ 291-394.

Herre (W.), 1955. - Das Ren als Haustier. Eine zoologische Monographie, Geest und Portig K.-G., Leipzig, 324 p.

-, 1963. - The science and history of domestic animals, pp. 235-249. In Science in archaeology. A comprehensive survey of progress and research. D. Brothwell and $\mathrm{E}$. Higgs, Eds. Basic Books, Inc., New York.

HNatiuk (J. M.), 1966. - First occurrence of Echinococcus multilocularis Leuckart, 1863 in Microtus pennsylvanicus in Saskatchewan. Canad. J. Zool. 44: 493.

Holmes (J. C.), 1961. - The importance of coyotes (Canis latrans) in the maintenance of sylvatic echinococcosis: Preliminary observations. J. Parasit., 47 (Suppl.): 55.

HoRnaday (W. T.), 1889. - The extermination of the American bison, Rept. U.S. Nat. Mus. 1886-87. U.S. Govt. Printing Off., Washington, pp. 369-548.

HUber (J. C.), 1881. - Studien und Beobachtungen über den multiloculären Echinococcus der Leber und der Nebenniere. 26. Bericht naturh. Ver. Augsburg., pp. 151-174.

Hudson (R. F.), 1861. - On hydatids. Austral. Med. J., $6:$ 75-88.

Hutchison (W. F.), 1960. - Studies on the hydatid worm, Echinococcus granulosus. II. Prevalence in Mississippi. Amer. J. Trop. Med. and Hyg., 9 : 612-615.

IABLoKov (D. D.), 1959. - Klinika al'veoliarnogo ekhinokokka pecheni, pp. 527-539. In Trudy Vsesibirsk. Konf. Terap., Revmatizm i parazitarnye zabolevaniia, 13-18 May 1958, Minist. zdravookhran. RSFSR, Novosibirsk, 616 p.

IARULIN (G. R.), 1958. - Izuchenie gel'mintofauny sobak i ekhinokokkoza v Dagestane. Tez. dokladov Nauch. Konf. Vsesoiuz. Obshchestva Gel'mint., 8-12 Dec. 1958, Moscow, pp. 188-189.

InGSTAD (H.), 1964. - Vinland ruins prove Vikings found the New World. Nat. Geogr. Mag., 126 : 708-734.

InUKaI (T.), YAMAShita (J.) and MoRi (H.), 1955. - Most probable route of introduction of Echinococcus into the Island of Rebun. J. Fac. Agric., Hokkaido Univ., 50: 134139.

Iogansen (G. Kh.), 1934. - Ptitsy Komandorskikh Ostrovov. Trudy Tomsk. Gosudarst. Univ., 86 : $222-266$.

IsHiNo (E.), 1941. - [Discussion about the development of alveolar type of Echinococcus]. (In Japanese). J. Animal Health Assoc., 9: 115-128.

IVASHKIN (V. M.), 1955. - Gel'minty sel'skokhoziaistvennykh zhivotnykh Mongol'skoi Narodnoi Respubliki, Trudy Mongol'. Komissii, vyp. 68, Kom. Nauk Mongol'. Narod. Respub., Akad. Nauk SSSR, Moscow, 216 p.

IvchenKo (N. S.), 1963. - Ekhinokokkoz i al'veokokkoz v Magadanskoi Oblasti (po materialam lechebnykh uchrezhdenii Magadana). Med. Parazit. i Parazit. Bolezni, 32 : 411-414.

JAMES (E.) and BoYD (W.), 1937. - Echinococcus alveolaris (with the report of a case). Canad. Med. Assoc. J., 36 : 354-356. 
JANSON (J. L.), 1893. - Die Haustiere in Japan. IV. Die Krankheiten der Haustiere in Japan. Arch. f. wiss. u. prakt. Thierheilk., 19 : 241-276.

Johansen (H.), 1950. - Polarraeven på Kommandørørne. Nat. Verd., 34 : 37-59.

JoHNSEN (S.), 1947. - Rovdyra, pp. 227-402. In Norges dyreliv. Vol. 1. Pattedyr. J. W. Cappelens Forlag, Oslo.

Kadenatsi (A. N.), 1953. - Opistorkhoz dikikh lisits v zapadnoi Sibiri, pp. 271-272. In Raboty po gel'mintologii, $k$ 75-let. Akad. K. I. Skriabina, Akad. Nauk SSSR, Moscow, $812 \mathrm{p}$.

- and Gerasimova (G. N.), 1958. - K gel'mintofaune ondatry Omskoi Oblasti. Tez. dokladov Nauch. Konf. Vsesoiuz. Obshchestva Gelmint., 8-12 Dec. 1958, Moscow, pp. 58-60.

KADYROV (N. T.), 1959. - K gel'mintofaune tonkogo otdela kishechnika sobak i dikikh plotoiadnykh zhivotnykh v Akmolinskoi Oblasti. Biull. Nauch.-tekh. Inf. Vsesoiuz. Inst. Gel'mint. im. K. I. Skriabina, $\mathrm{N}^{\circ}$ 5, pp. 30-36.

KARAMENDIN (O. S.), 1963. - K gel'mintofaune krupnogo rogatogo skota, importiruemogo iz Kitaia i Mongolii, pp. 123-125. In Materialy Nauch. Konf. Vsesoiuz. Obshchestva Gel'mint., 9-12 Déc. 1963, Pt. 1. Akad. Nauk SSSR, Moscow, 208 p.

KATZ (A. M.) and PAN (C.-T.), 1958. - Echinococcus disease in the United States. Amer. J. Med., $25: 759-770$.

KING (P. G.), 1793. - Captain Cook's last voyage to the Pacific Ocean; undertaken by command of His Majesty, for making discoveries in the northern hemisphere. Performed in the years 1776, 1777, 1778, 1779, 1780, M. Brown, Newcastle upon Tyne, $976 \mathrm{p}$.

KцемM (H.), 1883. - Zur Kenntnis des Echinococcus alveolaris der Leber. Münchener med. Wochenschr, 30: 451-455, 462-465.

KONDRAT'EV (V.P.), 1962. - Gel'mintofauna tonkikh kishechnikov sobak i dikikh plotoiadnykh zhivotnykh Kurganskoi Oblasti. Tez. dokladov Nauch. Konf. Vsesoiuz. Obshchestva Gel'mint., 10-14 Déc. 1962, Moscow, Pt. 1., pp. 88-90.

Kozlov (D. P.), 1961. - K obnaruzheniiu ekhinokokkov i al'veokokkov u zhivotnykh semeistva Canidae Khabarovskogo Kraia i Kamchatki. Trudy Gel'mint. Lab., 11 : 122-125.

—, Ovsiukova (N. I.) and RAdKevich (Zh. P.), 1963. - Gel'mintofauna zhivotnykh semeistva Canidae Chukotskogo Poluostrova (po materialam 318 SGE). pp. 66-70. In Gel'minty cheloveka, zhivotnykh $i$ rastenii $i$ bor'ba $s$ nimi. $K$ 85-let. Akad. $K$. $I$. Skriabina, Moscow, 524 p.

Kozman (J.) and Schanzel (H.), 1962. - Zur Kenntnis der Darmhelminthen des Fuchses. Angewandte Parasit., 3 : 16-19.

KudLICH (H.) and DicK (W.), 1960. - Der Echinokokkus alveolaris in Württemberg. Beitrag zur Verbreitung der Echinokokkenkrankheit, heutiger Stand der Therapie und Prognose. Med. Welt, 40: 2093-2100.

KuRAshviLI (B. E.), 1961. - O roli polevok i zakavkazskoi stepnoi lisitsy v epizootologii i epidemiologii al'veoliarnogo ekhinokokkoza v vostochnoi Gruzii. Soobshch. Akad. Nauk Gruz. SSR, 26: 309-315, 
-, 1962. - Ekhinokokkoz i al'veokokkoz v Gruzii. Tez. dokladov Nauch. Konf. Vsesoiuz. Obshchestva Gel'mint., 10-14 Déc. 1962, Moscow, Pt. 2, pp. 91-92.

Lafond (D. J.), Thatcher (D. S.) and Handeyside (R. G.), 1963. - Alveolar hydatid disease. J. Amer. Med. Assoc., 186: 141-143.

LANGer (W. L.), 1960. - An encyclopedia of world history, Houghton Mifflin Co., Boston. $1.243 \mathrm{p}$.

LAVRov (N.P.), 1953. - Vnutrennie i naruzhnye parazity ondatry. Trudy VNII Okhot. Promysla, $\mathrm{N}^{\circ} 12$, pp. 132-155.

Lehmensick (R.), 1964. - Trichinellose in Deutschland und Echinococcose in Afghanistan. Zeit. f. Parasitenk., 25 : 6-7.

LeIBY (P. D.), 1965. - Cestode in North Dakota: Echinococcus in field mice. Science, 150: 763.

一, and Olsen (O. W.), 1964. - The cestode Echinococcus multilocularis in foxes in North Dakota. Science, 145 : 1066.

LeIKINA (E. S.), 1957. - K voprosu o prirodnoi ochagovosti nekotorykh gel'mintozov. Med. Parazit. i Parazit. Bolezni, 26: 140-152.

-, 1959. - Novye dannye v epidemiologii ekhinokokkoza, pp. 539-545. In Trudy Vsesibirsk. Konf. Terap., Revmatizm i parazitarnye zabolevanïa, 13-18 May 1958. Minist. zdravookhran. RSFSR, Novosibirsk, 616 p.

—, Lukashenko (N. P.), Zorikhina (V. I.), Lavrenov (B. K.) and Mamedov (M. M.), 1959. $\mathrm{K}$ voprosu o prirodnykh ochagakh mnogokamernogo ekhinokokka $\mathrm{v}$ Novosibirskoi Oblasti. Med. Parazit. i Parazit. Bolezni, 28 : 206-213.

LESIN'sH (K. P.), 1959. - Izuchenie gel'mintofauny evropeiskoi ryzhei polevki (Clethrionomys glareolus) v Latviiskoi SSR. Fauna Latviiskoi SSR i Sopredel'nykh Territorii, Akad. Nauk Lat. SSR, 2 : 273-282.

Low (J.), 1822. - Cases of hydatids in the bladder and liver. N. Y. Med. and Physical J., $1: 287-289$.

LuKASHenKo (N. P.) and BRZHeskiI (V.V.), 1963. - Prirodnye ochagi trichinelleza i al'veokokkoza na Poluostrove Iamal. Med. Parazit. i Parazit. Bolezni, 32: 492.

-, and Zorikhina (V. I.), 1961. - Epidemiologiia al'veokokkoza (al'veoliarnogo ekhinokokkoza) v tsentral'nykh raionakh Barabinskoi lesostepi Novosibirskoi Oblasti. Med. Parazit. i Parazit. Bolezni, 30 : 159-168.

LuzhKov (A. D.), 1960. - K izucheniiu gel'mintofauny belykh pestsov Poluostrova Iamal. Trudy Nauch. Issled. Inst. Selsk. Krainego Severa, 8 : 52-54.

-, 1963 a. - Ekologo-parazitologicheskoe issledovanie belogo pestsa na Poluostrove Iamal. Zool. Inst., Akad., Nauk SSSR, Diss. Leningrad, pp. 3-19.

-, 1963 b. - K epizootologii i epidemiologii al'veokokkoza na Poluostrove Iamal. Med. Parazit. i Parazit. Bolezni, 32 : 180-183.

-, 1963 c. - Ekologo-parazitologicheskoe issledovanie belogo pestsa (Alopex lagopus L.) na Poluostrove Iamal. Zool. Zhur., 42: 964-966.

MACHUL'SKII (S. N.), 1958. - Gel'mintofauna gryzunov Buriatskoi ASSR. pp. 219-224. In Raboty po gel'mint. $k$ 80-let. Akad. K. I. Skriabina, Akad. Nauk SSSR, Moscow, 416 p. 
MacPherson (A. H.), 1965. - The origin of diversity in mammals of the Canadian arctic tundra. Syst. Zool., 14: 153-173.

MaGath (T. B.), 1941. - The epidemiology of hydatid (Echinococcus) disease in Canada and the United States. Arch. Intl. Hidat., 5: 55-80.

-, 1954. - The importance of sylvatic hydatid disease. J. Amer. Vet. Med. Assoc., 125: 411-414.

-, 1965. - Echinococcus multilocularis in a beef cow from the Middle West. Science, 147 : 632.

MALCZEWSKI (A.), 1963. - The red fox Vulpes vulpes L. as the final host of the tapeworm Echinococcus granulosus (Batsch, 1786) in Poland. Bull. Acad. Pol. Sci., 11: 295-296.

Mamedov (M. M.), 1960. - K voprosu o prirodnoi ochagovosti al'veoliarnogo ekhinokokkoza v Turukhanskom raione Krasnoiarskogo Kraia. Med. Parazit. i Parazit. Bolezni, 29: $157-161$.

-, 1964. - K voprosu o rasprostranenii ekhinokokkoza i al'veokokkoza $\mathbf{v}$ Azerbaidzhanskoi SSR. Med. Parazit. i Parazit. Bolezni, 33: 278-283.

ManKaU (S. K.), 1956 a. - Studies on Echinococcus alveolaris (Klemm, 1883), from St. Lawrence Island, Alaska. III. The histopathology caused by the infection of $E$. alveolaris in white mice. Amer. J. Trop. Med. and Hyg., 5: 872-880.

-, 1956 b. - Studies on the helminth, Echinococcus alveolaris (Klemm, 1883), from St. Lawrence Island, Alaska. II. Development of brood capsules and scolices in alveolar cysts, in white mice. Trans. Amer. Micr. Soc., 75: 401-406.

-, 1957. - Studies on Echinococcus alveolaris (Klemm, 1883), from St. Lawrence Island, Alaska. I. Histogenesis of the alveolar cyst in white mice. J. Parasit., 43: 153-159.

MARTIKIAN (E.S.), 1963. - Nekotorye voprosy ekhinokokkoza v Armianskoi SSR. Med. Parazit. i Parazit. Bolezni, 32: 184-188.

MARTIN (J.-F.) and Tisserand (G.), 1922. - Le quatrième cas français authentique d'échinococcose alvéolaire du foie chez l'homme. J. Méd. Lyon, 3: 447-452.

Meade (J. A.), and BarnetT (L.), 1941. - Echinococcosis alveolaris (alveolar hydatid disease), associated with ordinary hydatid cysts of the liver. Austral. and New Zealand J. Surg., $10: 317-327$.

Merdivenci (A.), 1962. - Manda (Buffelus bubalus) karaciğerinde Echinococcus multilocularis Leuckart, 1863 (Syn ; E. alveolaris Klemm, 1883) Müsahedesi. (English summary). Türk. Vet. Hekim. Derneği Dergisi, 32: 117-124.

Michon (P.), Larcan (A.) and Streiff (F.), 1961. - L'échinococcose alvéolaire du foie. Rev. du Pratic., 11: 73-77.

Miroshnikova (A. I.), 1964. - Materialy po al'veokokkozy (al'veoliarnomu ekhinokokkozu) v Omskoi Oblasti. Med. Parazit. i Parazit. Bolezni, 33 : 494.

Neghme (A.), 1958. - The significance of echinococcosis in the Americas. Proc. 6th Intl. Cong. Trop. Med. and Malaria, 2 : 552-567.

Nelson (G. S.) and Rausch (R. L.), 1963. - Echinococcus infections in man and animals in Kenya. Ann. Trop. Med. and Parasit., 57 : 136-149. 
-, Pester (F. R. N.) and Rickman (R.), 1965. - The significance of wild animals in the transmission of Cestodes of medical importance in Kenya. Trans. Roy. Soc. Trop. Med. Hyg., 59: 507-524.

Nenow (S.), 1960. - Wystepowanie bablowćow (Echinococcus) w Bułgarii. Wiad. Parazyt., $6: 31-40$.

Nikitin (V.F.), 1959. - O vidovom sostave ekhinokokkov u sobak i lisits $v$ Dagestane. Trudy Vsesoiuz. Inst. Gel'mint. im. Akad. K. I. Skriabina, 7: 125-128.

-, 1960. - K gel'mintofaune sobak i lisits v Dagestanskoi ASSR. Tez. dokladov Nauch. Konf. Vsesoiuz. Obshchestva Gel'mint., 15-20 Dec 1960. Moscow. pp. 96-98.

—, 1962 a. - Gel'minty tonkogo otdela kishechnika sobak v Dagestane i sezonnaia dinamika ikh chislennosti. Trudy Vsesoiuz. Inst. Gel'mint. im. Akad. K. I. Skriabina, 9: 45-58.

—, 1962 b. - K gel'mintofaune lisits v Dagestane. Trudy Vsesoiuz. Inst. Gel'mint. im. Akad. K. I. Skriabina, 9: 59-60.

OGNev (S. I.), 1950. - Zveri SSSR i prilezhashchikh stran. Vol. 7. Gryzuny. Akad. Nauk SSSR, Moscow-Leningrad, 706 p.

OHNo (S.), JAINChill (J.) and Stenius (C.), 1963. - The creeping vole (Microtus oregoni) as a gonosomic mosaic. I. The OY/XY constitution of the male. Cytogen. 2: 232-239.

OshmaRIN (P. G.), 1963. - Paraziticheskie chervi mlekopitaiushchikh i ptits Primorskogo Kraia. Sibir. Otdelenie, Dal'nevostoch. Filial im. V. L. Komarova, Akad. Nauk SSSR, Moscow, 323 p.

OsLer (W.), 1882. - On echinococcus disease in America. Amer. J. Med. Sci. 84: 475-480.

Ovsıukova (N. I), 1963. - K izucheniiu gel'mintofauny mlekopitaiushchikh Chukotskogo Poluostrova. Trudy Vsesoiuz. Inst. Gel'mint. im. Akad. K.I. Skriabina, 10: 13-15.

Oytun (H. S.), 1957. - Hydatidose in der Türkei. Zeit. f. Trop. Med. u. Parasit., 8: 196200.

Pantiukhov (A. M.), 1962. - Ekhinokokkovaia bolezn' v Pavlodarskoi Oblasti. Tez. dokladov Nauch. Konf. Vsesoiuz. Obshchestva Gel'mint., 10-14 Dec. 1962, Moscow, Pt. 2, pp. $149-150$.

Paramananthan (D. C.) and Dissanaike (A. S.), 1961. - Sylvatic hydatid infection in Ceylon. Trans. Roy. Soc. Trop. Med. Hyg., $55: 483$.

PAutov (F. N.), 1964. - Ekhinokokkoz u cheloveka po materialam prozektur goroda Omska za period c 1941 po 1962 g. Med. Parazit. i Parazit. Bolezni, 33 : 283-286.

Pérez Fontana (V.), 1949. - Origen, desarrolo y extensión de la hidatidosis en América. Bol. Ofic. Sanit. Panam., 28 : 124-156.

Petrov (A. M.), 1957. - Sovremennye vozzreniia na epizootologiiu i epidemiologiiu ekhinokokkozov. Tez. dokladov Nauch. Konf. Vsesoiuz. Obshchestva Gel'mint., 11-15 Dec. 1957, Moscow, Pt. 2, pp. 12-14.

- and Chertkova (A. N.), 1959. - Otlichitel'nye priznaki odnokamernogo i al'veoliarnogo ekhinokokkov po lichinochnym i polovozrelym formam. Trudy Vsesoiuz. Inst. Gelmint. im. Akad. K. I. Skriabina, 7 : 129-139.

- and Delianova (R. Sh.), 1962. - Rasprostranenie vozbuditelei ekhinokokkoza i al'veokokkoza u domashnikh i dikikh plotoiadnykh v SSSR. Trudy Vsesoiuz. Inst. Gel'mint. im. Akad. K. I. Skriabina, 9 (Pt. 1) : 67-87. 
- and LuKashenko (N. P.), 1962. - Rol' koshek v epidemiologii ekhinokokkoza i al'veokokkoza. Med. Parazit. i Parazit. Bolezni, 31 : 223-228.

Petukhov (M. I.), 1957. - Rasprostranenie i lechenie ekhinokokkovoi bolezni v Kuibyshevskoi Oblasti. Khirurg., $33: 85-89$.

Pod'IAPOL'SKAIA (V.P.) and KAPUSTIN (V.F.), 1958. - Glistnye bolezni cheloveka. Gosudarst. Izdat. Med. Lit., Medgiz-Moscow, 663 p.

Posselt (A.), 1925. - Ueber Klinik und Pathologie des Alveolarechinococcus der Leber, seine geographische Verbreitung, insbesonders sein Vorkommen in den Alpenländern, speziell Tirol. Schweiz. med. Wochenschr., 55 : 593-605.

—, 1936. - Uber die Natur des Echinococcus alveolaris und seine Beziehung zum Echinococcus hidatidosus. 3rd Intl. Cong. Path. Comp., Sect. Med. Hum., 1: 27-55.

Prokopič (J.), 1960. - Helmintofauna divokých a pěstovaných lišek v Československu. Zool. Listy, Folia Zool., 23 : 239-244.

Protasova (A.F.), 1965. - O mnogokamernom ekhinokokkoze (al'veokokkoze) v Kirovskoi Oblasti. Med. Parazit. i Parazit. Bolezni, 34 : 230-231.

Ramazanov (V.T.), 1963. - Endemicheskii ochag al'veokokkoza v Alma-Atinskoi Oblasti i rol' sobak v rasprostranenii etoi invazii, pp. 51-53. In Gel'minty cheloveka, zhivotnykh $i$ rastenii $i$ bor'ba s nimi. K 85-let. Akad. K. I. Skriabina, Moscow, 524 p.

Rausch (R. L.), 1952. - Hydatid disease in boreal regions. Arctic, 5 : 157-174.

- 1953 a. - The taxonomic value and variability of certain structures in the Cestode genus Echinococcus (Rud. 1801) and a review of recognized species. Thapar Commem. Vol., Lucknow, pp. 233-246.

-, 1953 b. - On the land mammals of St. Lawrence Island, Alaska. Murrelet, 34: 18-26.

-, 1954. - Studies on the helminth fauna of Alaska. XX. The histogenesis of the alveolar larva of Echinococcus species. J. Inf. Dis., $94: 178-186$.

-, 1956. - Studies on the helminth fauna of Alaska. XXX. The occurrence of Echinococcus multilocularis Leuckart, 1863, on the mainland of Alaska. Amer. J. Trop. Med. and Hyg., 5 : 1086-1092.

-, 1957. - Distribution and specificity of helminths in microtine rodents: evolutionary implications. Evol., $11: 361-368$.

-, 1958. - Echinococcus multilocularis infection. Proc. 6th Intl. Cong. Trop. Med. and Malaria, 2: 597-610.

-, 1960. - Recent studies on hydatid disease in Alaska. Parassit., 2 : 391-398.

-, 1963. - A review of the distribution of holarctic recent mammals. Pac. Basin Biogeogr., 10th Pac. Sci. Cong. 1961, Bishop Mus. Press, Honolulu, pp. 29-43.

- and Nelson (G.S.), 1963. - A review of the genus Echinococcus Rudolphi, 1801. Ann. Trop. Med. and Parasit., 57 : 127-135.

- and Schiller (E. L.), 1951. - Hydatid disease (Echinococcosis) in Alaska and the importance of rodent intermediate hosts. Science, $113: 57-58$.

- , - 1956. - Studies on the helminth fauna of Alaska. XXV. The ecology and public health significance of Echinococcus sibiricensis Rausch \& Schiller, 1954, on St. Lawrence Island. Parasit., 46 : 395-419.

- and Yamashita (J.), 1957. - The occurrence of Echinococcus multilocularis Leuckart, 1863, in Japan. Proc. Helminth. Soc. Wash., 24 : 128-133. 
REED (C. A.), 1960. - A review of the archaeological evidence on animal domestication in the prehistoric Near East, pp. 119-145. In Prehistoric investigations in Iraqi Kurdistan by R. J. Braidwood and B. Howe. Univ. Chicago Press, 184 p.

Rico (C. M.), 1961. - El unicismo en la evolución hidática. Arch. Intl. Hidat., 20: 183-193.

-, 1963. - Valoración crítica sobre la unidad o dualismo del parásito equinococósico. Arch. Intl. Hidat., 21 : 170-175.

RIKHTER (G. D.), 1961. - Prirodnoe raionirovanie SSSR. Izvest. Akad. Nauk SSSR, Ser. Geograf. 1961, No. 3, pp. 3-13.

RILEY (W. A.), 1933. - Reservoirs of Echinococcus in Minnesota. Minn. Med., 16: 744745.

Roman (C.), 1956. - Nota sobre incidencia de hidatidosis en alpacas y ovinos de la sierra del Peru. Rev. Med. Exper., 10 : 85-87.

Romanov (I. V.), 1962. - K gel'mintofaune dikikh lisits Srednego Povolzh'ia. Tez. dokladov Nauch. Konf. Vsesoiuz. Obshchestva Gel'mint., 10-14 Dec. 1962, Moscow, Pt. 1, pp. $145-146$.

-, 1964. - Gel'mintofauna lisitsy v Gor'kovskoi Oblasti. Zool. Zhur., 43: 1610-1617.

Romero-Torres (R.) and CAMpbell (J. R.), 1965. - An interpretive review of the surgical treatment of hydatid disease. Surg., Gynecol. and Obstet., 121: 851-864.

SADYKHоv (I. A.), 1953. - K izucheniiu gel'mintofauny shakalov Azerbaidzhana, pp. 620-621. In Raboty po Gel'mint. $k$ 75-let. Akad. K. I. Skriabina, Akad. Nauk SSSR, Moscow, $812 \mathrm{p}$.

SADYKOV (V. M.), 1963. - Rasprostranenie vozbuditelei ekhinokokkoza i al'veokokkoza u sobak i lisits v Uzbekistane, pp. 61-62. In Gel'minty cheloveka, zhivotnykh $i$ rastenii i bor'ba s nimi. K 85-let. Akad. K. I. Skriabina, Moscow, 524 p.

Saemundsson (B.), 1939. - Mammalia. In The Zoology of Iceland. Vol. 4, Pt. 76. Munksgaard, Copenhagen and Reykjavik, 53 p.

Salmon (D. E.), 1901. - Pathological conditions found in meat inspection. J. Amer. Med. Assoc., 36: 867-871.

Santivanez M. (J.) and Cuba C. (A.), 1949. - Quiste hidatico en Lama glama pacos o alpaca. Rev. Fac. Med. Vet. Lima, 4 : 22-24.

Schmid (R.), 1958. - Die Echinokokken-Krankheit in der Schweiz, 1926-1955. Acta Trop., $15: 65-81$.

SchWARTZ (B.), 1925. - Internal metazoan parasites collected from ruminants in the Philippine Islands. Phil. J. Sci., 26: 521-533.

SchWARZ (E.), 1928. - Die Echinokokkenkrankheit. II. Teil. Die geographische Verbreitung der Echinokokkenkrankheit. N. Deutsche Chir., $40: 67-114$.

Semenov (V.S.), 1954. - O rezektsii pecheni po povodu al'veoliarnogo ekhinokokka. Vestnik Khir., $74: 20-25$.

—, 1960. - Al'veoliarnyi ekhinokokkoz kak kraevaia patologiia $\mathrm{v}$ usloviiakh Iakutskoi ASSR. Sovet. Med., 24 : 57-62.

SHARPILO (L. D.), 1961. - K izucheniiu gel'mintofauny gryzunov na territorii Ukrainy, pp. 201-206. In Problemy parazitologii. Trudy Ukrain. Respub. Nauch. Obshchestva Parazit. No. 1. Kiev, 367 p. 
Shul'man (E. S.), 1958. - Nozogeografiia gel'mintozov cheloveka na Ukraine. Tez. dokladov. Nauch. Konf. Vsesoiuz. Obshchestva Gel'mint., 8-12 Dec. 1958, Moscow, pp. 180 182.

Shumakovich (E. E.) and Nikitin (V. F.), 1959. - K obnaruzheniiu Echinococcus granulosus (Batsch, 1786) u korsaka. Biull. Nauch.-tekhn. Inf. Vsesiouz. Inst. Gel'mint. im. K. I. Skriabina, No. 5, pp. 98-99.

Sirvonen (L.), 1956. - Suuri nisäkäskirja, Kustannusosakeyhtiö Otava, Helsinki, 800 p.

SoKolov (N. P.), 1954. - Materialy k izucheniiu ekhinokokkovoi bolezni v Karagandinskoi Oblasti. Med. Parazit. i Parazit. Bolezni, 23 : 313-317.

SorochenKo (E. V.), 1964. - K voprosu o rasprostranenii ekhinokokkozov v Nenetskom Natsional'nom Okruge. Med. Parazit. $i$ Parazit. Bolezni, 33 : 287-289.

SowiakowsKI (J.), 1955. - Bablowiec wielopecherzowy (Echinococcus alveolaris). Pol. Tyg. Lek., $10: 46-52$.

Spasski (A. A.), Romanova (N. P.) and Naidenova (N. V.), 1951. - Novye dannye o faune paraziticheskikh chervei ondatry-Ondatra zibethica (L.). Trudy Gel'mint. Lab., 5 : $42-52$.

-, RyzhiKov (K. M.) and Sudarikov (V. E.), 1952. - Gel'mintofauna dikikh mlekopitaiushchikh zony Ozera Baikal. Trudy Gel'mint. Lab., 6: 85-113.

Stejneger (L.), 1884. - Contributions to the history of the Commander Islands. No. 1. Notes on the natural history, including the descriptions of new cetaceans. Proc. U.S. Nat. Mus., 6 : 58-89.

Sterman (M. M.) and Brown (H. W.), 1959. - Echinococcus in man and dog in the same household in New York City. J. Amer. Med. Assoc., 169: 938-940.

StunKard (H. W.), 1957. - Host-specificity and parallel evolution of parasitic flatworms. Zeit. Tropenmed. u. Parasit., 8 : 254-263.

Suić (M.), 1951. - L'échinococcose en Yougoslavie. Afr. Franc. Chir., 4: 427-430.

-, 1952. - Ehinokokoza. Jugoslav. Akad. Znanosti i Umjetnosti, Zagreb, 206 p.

Sulrmov (A. D.), 1963. - Gel'mintofauna gryzunov tuvinskoi ASSR, pp. 111-115. In Materialy Nauch. Konf. Vsesoiuz. Obshchestva Gel'mint., 9-12 Dec. 1963, Pt. 2. Akad. Nauk SSSR, Moscow, 196 p.

Sweatman (G. K.) and Williams (R. J.), 1962. - Wild animals in New Zealand as hosts of Echinococcus granulosus and other taeniid tapeworms. Trans. Roy. Soc. New Zealand (Zool.), 2: 221-250.

- , - 1963. - Comparative studies on the biology and morphology of Echinococcus granulosus from domestic livestock, moose and reindeer. Parasit., $53:$ 339-390.

Szidat (L.), 1960. - Echinococcus patagonicus sp. nov. (Cestoda) parasito del zorro Dusicyon culpaeus culpaeus (Mol.). Neotrop., 6: 13-16.

-, 1963. - Studien über den Erreger der alveolären Echinococcenkrankheit des Menschen in Südamerika. Zeit. Parasit., $23: 80-91$.

TAhsinoglu (M.) and Hacihanefioglu (U.), 1962. - Echinococcus alveolaris'in Türkiyede bugünkü durumu. (English summary). Ist. Tip Fak. Mec., 25 : 289-294.

Tasselli (E.), 1963. - Indagini sulla idatidosi in Provincia di Foggia. Ann. San. Pub. Roma, $24: 619-660$. 
Thomas (L. J.) and Babero (B. B.), 1956. - Some helminths of mammals from St. Lawrence Island, Alaska, with a discussion on the nomenclature of Echinococcus in voles. J. Parasit., 42 : 500.

-, -, Gallicchio (V.) and Lacey (R. J.), 1954. - Echinococcosis on St. Lawrence Island, Alaska. Science, 120 : 1102-1103.

Thorarinsson (S.), 1960. - Iceland, pp. 203-233. In A geography of Norden. A. Sømme, Ed. J. W. Cappelens Forlag, Oslo, 363 p.

Tоковаеv (M. M.), 1959. - Gel'mintofauna gryzunov Kirgizii. Akad. Nauk Kirgiz. SSR, Inst. Zool. i Parazit., vyp. 7, pp. 133-142.

-, 1960. - Gel'mintofauna gryzunov Kirgizii. Trudy Gel'mint. Lab., 10: 235-247.

Tubangui (M. A.), 1925. - Metazoan parasites of Philippine domesticated animals. Phil. J. Sci., $28: 11-37$.

VAN Deinse (A. B.), 1957. - The spread of echinococcosis. Doc. Med. Geograph. et Trop., 9: 158-164.

VAngengeim (E. A.), 1961. - Paleontologicheskoe obosnovanie stratigrafii antropogenovykh otlozhenii severa vostochnoi Sibiri. Trudy Geolog. Inst., Akad. Nauk SSSR, Moscow. Vyp. 48,182 p.

Verster (A. J. M.), 1965. - Review of Echinococcus species in South Africa. Onderstepoort J. Vet. Res., 32: 7-118.

VIBE (P. P.), 1961. - K gel'mintofaune sobak Semipalatinskoi Oblasti. Akad. Nauk Kazakh. SSR, Prirod. Ochagovost' Boleznei i Voprosy Parazit., vyp. 3, pp. 302-303.

VIERORDT (H.), 1886. - Abhandlung über den multiloculären Echinococcus. Akad. Verlagsbuchhandl., Freiburg i. B. 172 p.

Vinogradov (B. S.) and Gromov (I. M.), 1952. - Gryzuny fauny SSSR. Akad. Nauk SSSR, Moscow-Leningrad, 297 p.

VIRchow (R.), 1855. - Die multiloculäre, ulcerirende. Echinokokkengeschwulst der Leber. Verhandl. phys.-med. Gesellsch. Würzburg, 6: 84-95.

Vogel (H.), 1955. - Ùber den Entwicklungszyklus und die Artzugehörigkeit des europäischen Alveolarechinococcus. Deutsche Med. Wochenschr., 80: 931-932.

-, 1957. - Über den Echinococcus multilocularis Süddeutschlands. I. Das Bandwurmstadium von Stämmen menschlicher und tierischer Herkunft. Zeit. Tropenmed. $u$. Parasit., 8 : 404-454.

-, 1960. - Tiere als natürliche Wirte des Echinococcus multilocularis in Europa. Zeit. Tropenmed. u. Parasit., $11:$ 36-42.

—, 1961. - Biologie und Parasitologie des Alveolärechinokokkus. Chir. Prax., 5: 407-412.

VоLокн (Iu. A.), 1957. - Ekhinokokkovaia bolezn' u liudei. Akad. Nauk Kirgiz. SSR, Frunze, 259 p.

Von Siebold (C. T. E.), 1853. - Über die Verwandlung der Echinococcus-Brut in Taenien. Zeit. Wissensch. Zool., 4 : 409-425.

VSEVOLODOV (B. P.), 1953. - K patomorfologii gel'mintozov ondatry, pp. 106-114. In Raboty po Gel'mint. $k$ 75-let. Akad. K. I. Skriabina. Akad. Nauk SSSR, Moscow, 812 p.

Walshe (J. M.), 1954. - Echinococcosis alveolaris of the liver. J. Path. Bact., 67: 371-377. 
Weinberg (T.), 1947. - Echinococcus alveolaris infection of the human liver. J. Mt. Sinai Hosp., 13 : 331-336.

West (J. T.), Hillman (F. J.) and Rausch (R. L.), 1963. - Alveolar hydatid disease of the liver: rationale and technics of surgical treatment. Ann. Surg., 157: 548-559.

WETZEL (R.) and RIECK (W.), 1962. - Krankheiten des Wildes. Feststellung, Verhütung und Bekämpfung. Ein Leitfaden für Jäger, Tierärzte, Biologen und Landwirte. Paul Parey, Hamburg-Berlin, 223 p.

WodzICKI (K. A.), 1950. - Introduced mammals of New Zealand. Dept. Sci. and Indust. Res., Bull. 98, 255 p.

Yamashita (J.), 1956. - Studies on echinococcosis. II, Echinococcosis in Japan. Japan. J. Vet. Res., $4:$ 64-74.

-, ONo (Z.), TAKahashi (H.) and Hattori (K.), 1955. - [On the occurrence of Echinococcus granulosus (Batsch, 1786) Rudolphi, 1805 in the dog in Rebun Island, and the discussion about the course of infection of the echinococcosis]. (In Japanese). Mem. Fac. Agric. Hokkaido Univ., 2: 147-150.

Yasarol (S.), 1960. - L'hydatidose-échinococcose en Turquie. Bull. Off. Intl. Epizoot., 54 : 492-501.

ZAKHRIALOV (Ia. N.), 1958. - Gel'mintofauna domashnikh svinei i dikikh kabanov iugovostoka Kazakhstana. Trudy Inst. Zool. Akad. Nauk Kazakh. SSR, 9: 92-103.

Zapatel (J.), Guerrero (C.) and Escalante (J.), 1962. - Hidatidosis en el Peru. Bol. Ofic. San. Panam., 52: 296-308.

Zeller (E.), 1854. - Alveolarcolloid der Leber. Inaug. Diss., Tübingen, 28 p.

ZeUner (F. E.), 1958. - Dating the past. An introduction to geochronology. Methuen and Co., Ltd., London, 516 p.

-, 1959. - The pleistocene period. Its climate, chronology and faunal successions, Hutchinson, London, $447 \mathrm{p}$.

Zhavoronkov (A. A.), 1962. - Al'veoliarnyi ekhinokokk pecheni. Arkh. Pat., 24: 75-77.

Zikeeva (A.I.) and Arslanova (A. Kh.), 1961. - Nekotorye sravnitel'nye dannye po patomorfologii al'veokokkoza (al'veoliarnogo ekhinokokkoza) ondatry i cheloveka. Helminth., 3 : 440-447.

(Arctic Health Research Center, Public Health Service,

U.S. Department of Health, Education, and Welfare, Fairbanks, Alaska) 